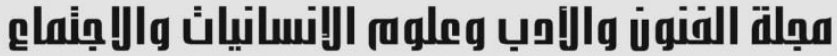

Journal of Arts, Literature, Humanities and Social Sciences www.jalhss.com

\section{تأويل المتشابه اللفظي عند الامام الرازي سورة الكهف إنموذجا الأمام (دراسة موضوعية)}

أ.م. د. إسراء كريم عبدالله كلية التربية للبنات ـ الجامعة العراقية النية ـ العراق

\section{الماخص}

إن علم التفسير من اجل العلوم كونه يتعلق بكتاب اله ،و إن شرف كل علم بشرف متعلقة ، ولما كان التفسير متعلق بكتاب الهه ؛ لذا اخذ هذه الاهمية من اهمبة القرآن ومكانته السامية . وقد اعتنى العلماء قديما وحديثا بتفسير القرآن الكريم والغوص في كلماته و عبار اته ؛ليستخرجوا لنا دررا ثمينة ومعان عجيبة ، وقد تعددت مناهج بالمفسرين واختلفت اتجاهاتهم ،فكل منهم يغترف من القرآن بحسب منهجه واتجاهه ، وقد برز لنا من بين هذه الاتجاهات اتجاه بعنى بتأويل المنتابه في القرآن الكريم ،فأفردوا لنا كتب في التأويل كالغرناطي والاسكافي ،بينما حاول بعض المفسرين الأخرين الحديث عن التأويل من خلال تفسير هم للقر آن وفق المنهج الذي اعتمدوه كالزمخشري و الرازي الذي يعد من ابرز العلماء الذين تحدثوا عن تأويل المتشـابه حيث وقف عند الآيات وفصل القول فيها ، ومن هنا جاءت فكرة البحث ، حيث تناولت تأويلات الرازي للمنشابه في سورة الكهف ،فكان العنوان (تأويل المتشابه عند الامام الرازي ـ سورة الكهف إنموذجا) وقد اقتضت طبيعة البحث أن يقسم الى أربعة مباحث ، بالاضافة الى مقدمة ،وخاتمة . تناولت في البحث الاول التعريف بمصطلحات البحث ،وفيه مطالب : المطلب الأول/ تعريف (التأويل ) لغة ، و اصطلاحاً ، و المطلب الثاني / تعريف ( المنشابه اللفظي ) لغة ، و اصلاحاً ـ ، اما البحث الثاني : بين بدي السورة ، وفيه مطالب : المطلب الاول : أسمها ،و عدد آياتها ، ومكان نزولها ، المطلب الثاني : سبب نزولها ، المطلب الثالث :موضو عاتها ، المطلب الر ابع : فضل السورة كوالمبحث الثالث : المبحث الثالث عن تأويل المتشنابه الذي انفرد به الامام الرازي ، ولم يذكره علماء المنتـابه، اما المبحث الرابع والاخير كان عن تأويلات الرازي التي ذكر ها علماء المتشابه ، ثم ختمت البحث بأهم النتائج التي توصلت اليها مع ذكر التوصيات . الكلمات المفتاحية: التأويل، المتشابه اللفظي، الامام الرازي، سورة الكهف. 


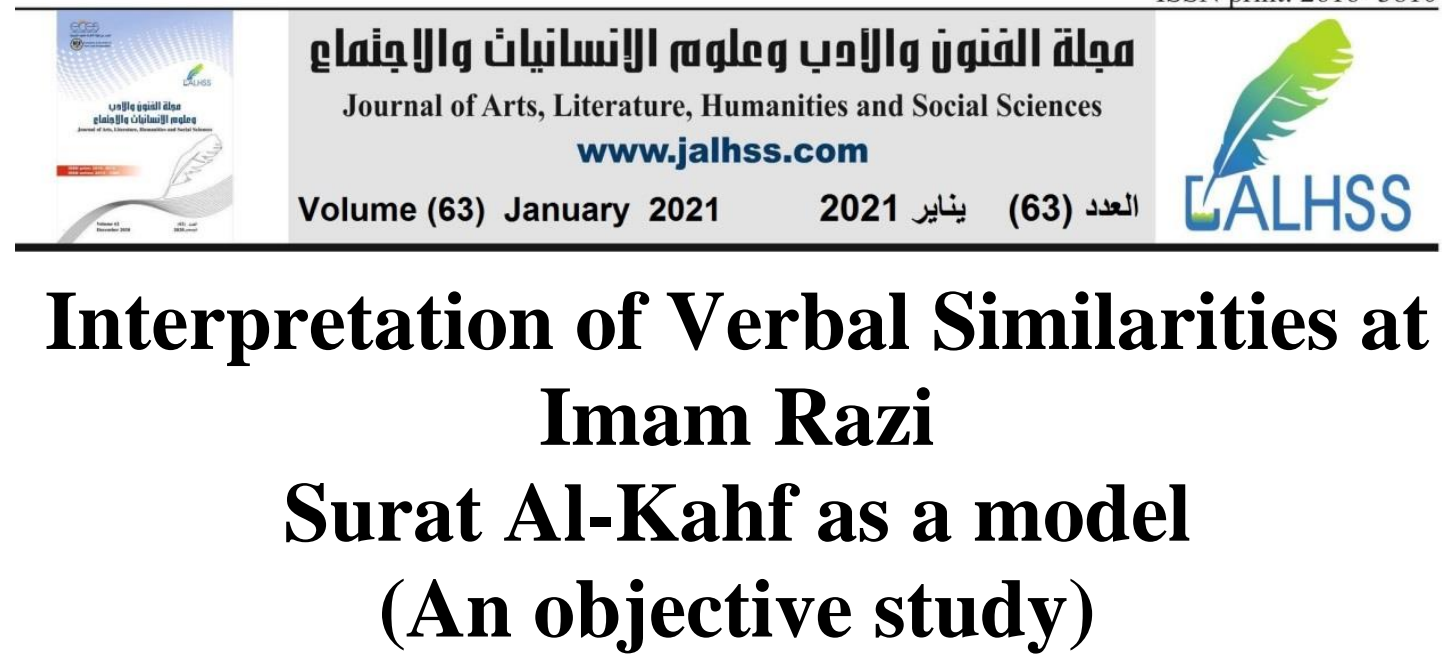

Assist. Prof. Dr. Israa Karim Abdullah

College of Education for Girls - Iraqi University - Iraq

\begin{abstract}
The science of exegesis for the sake of the sciences is related to the book of God, and the honor of each knowledge is related to honor, and since interpretation is related to the book of God; Therefore, he took this importance from the importance of the Qur'an and its sublime status. The scholars, in the past and present, took care of the interpretation of the Noble Qur'an and dived into its words and phrases, to extract for us precious pearls and wonderful meanings. So they singled out for us books on hermeneutics such as alGharnati and al-Iskafi, while some other commentators tried to talk about exegesis through their interpretation of the Qur'an according to the method they adopted, such as al-Zamakhshari and al-Razi, which is one of the most prominent scholars who spoke about the interpretation of the similarity as he stood at the verses and separated the saying about them, and from here came the idea of research Where I dealt with AlRazi's interpretations of the similarity in Surat Al-Kahf.

The nature of the research required that it be divided into four sections, in addition to an introduction and a conclusion.

In the first research I dealt with the definition of search terms, and it includes the requirements: the first requirement / definition of (interpretation) language and idiom, and the second requirement / definition of (verbal similarity) language, and reform. As for the second research: in the hands of the surah, and it includes demands: the first requirement: its name, the number of its verses, and the place of its descent, the second requirement: the reason for its revelation, the third requirement: its topics, the fourth requirement: the merit of the surah, and the third topic: the third study on the interpretation of the similarity that was unique By Imam al-Razi, and scholars of the similarity did not mention it. As for the fourth and final study, it was about the interpretations of al-Razi that were mentioned by the scholars of the similarity.
\end{abstract}

Keywords: Al-Ta`wil, Verbal Similarities, Al-Imam Al-Razi, Surat Al-Kahf. 


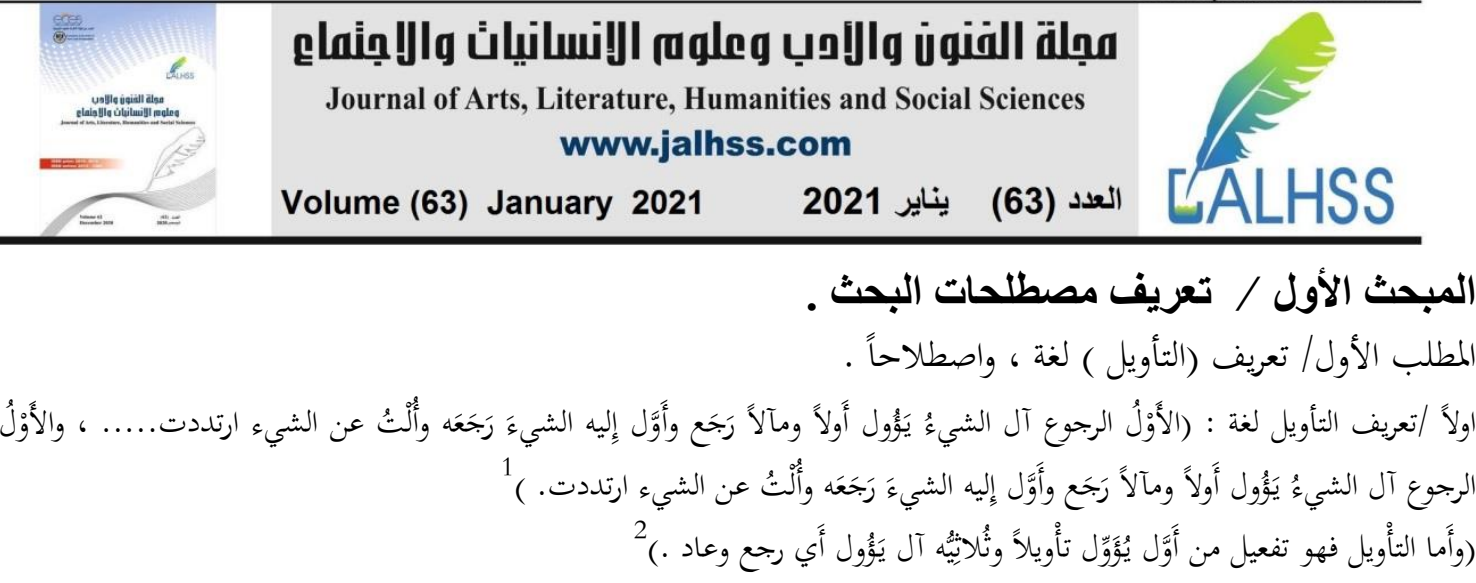

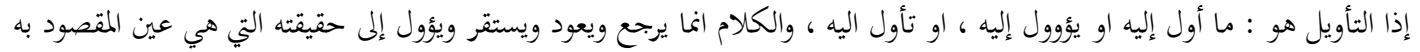

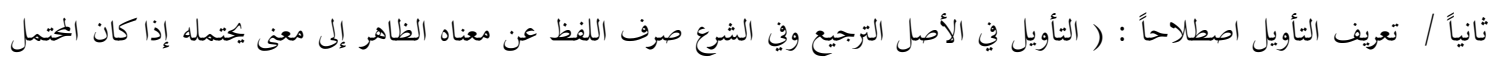

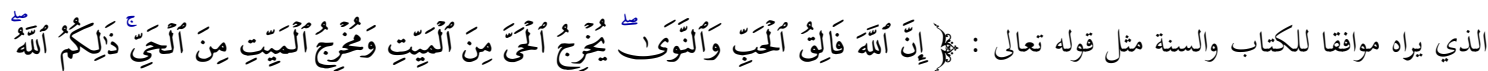

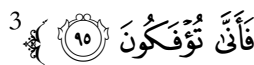

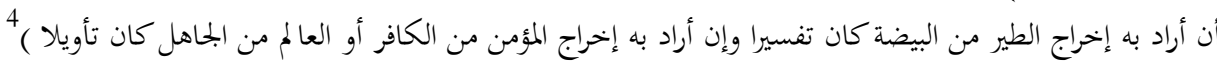

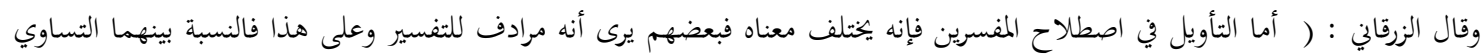

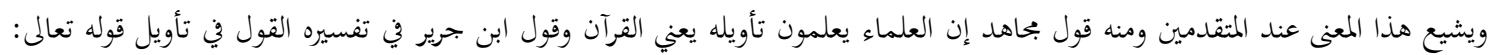
كذا واختلف أهل التأويل في هذه الآية.

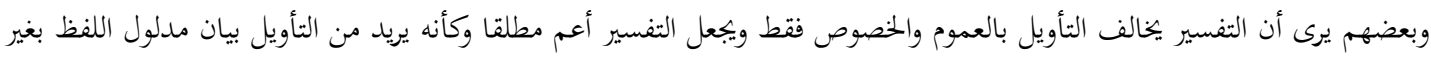

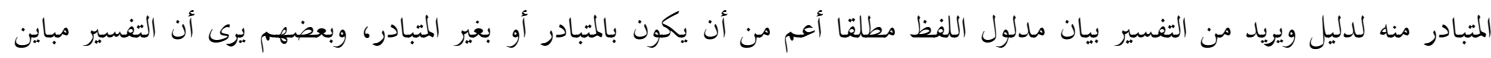

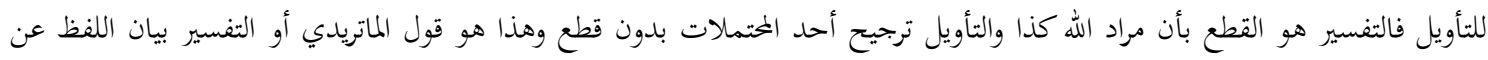

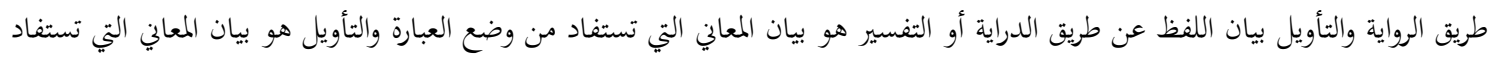

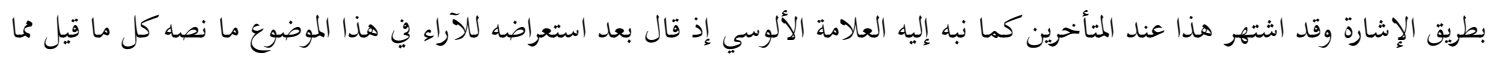

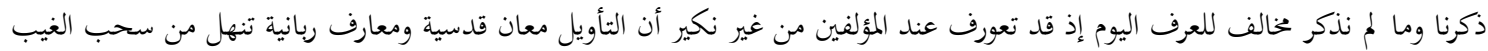
على قلوب العارفين والتفسير غير ذلك.

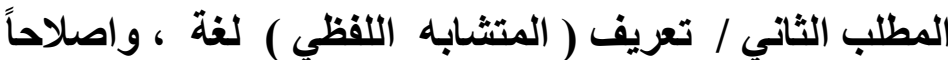

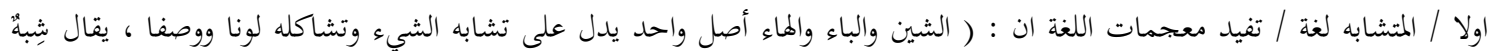

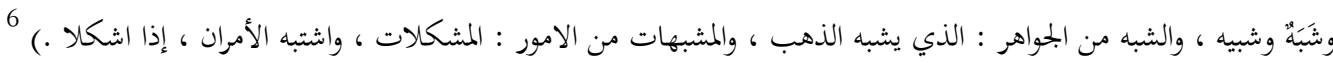

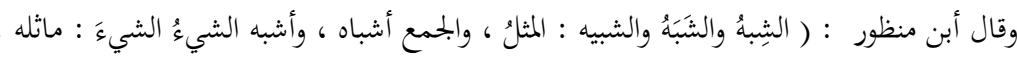

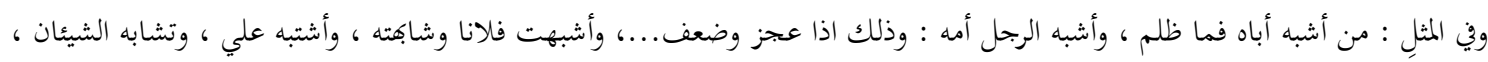

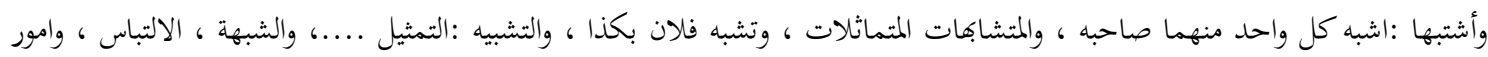

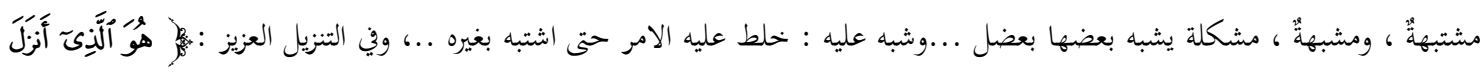




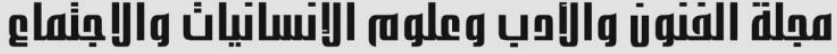

Journal of Arts, Literature, Humanities and Social Sciences www.jalhss.com

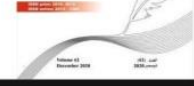

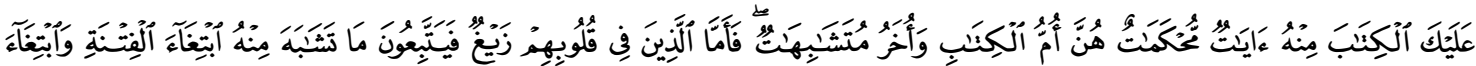

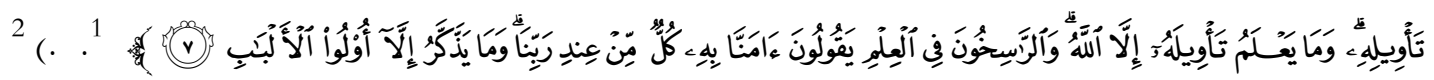

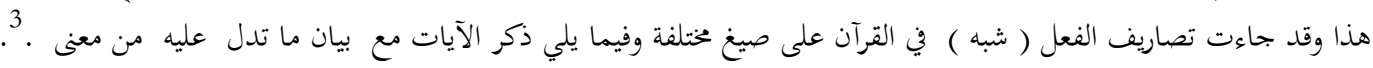

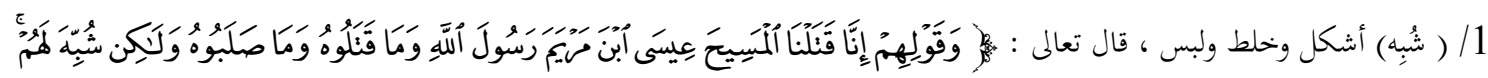

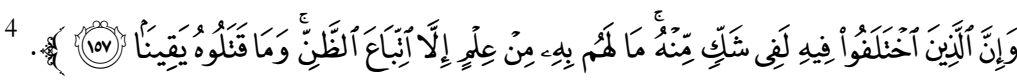

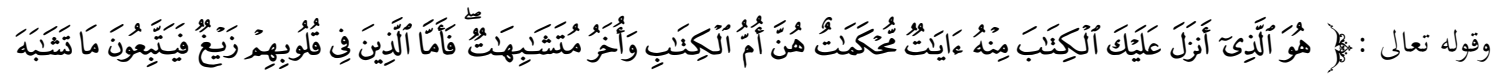

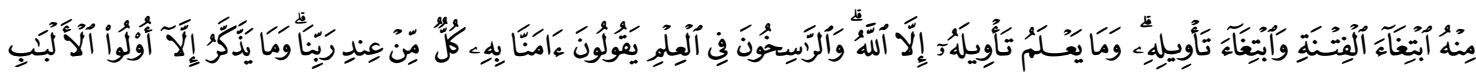

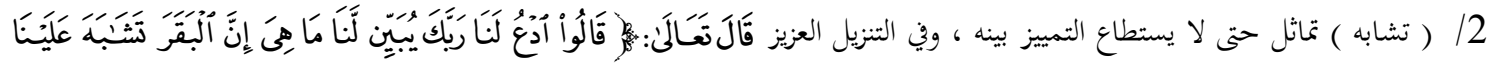

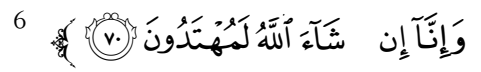

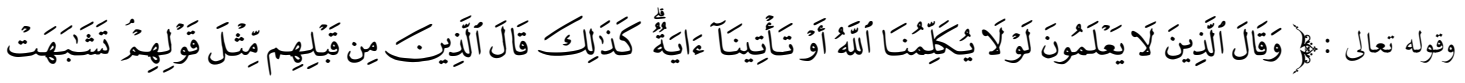

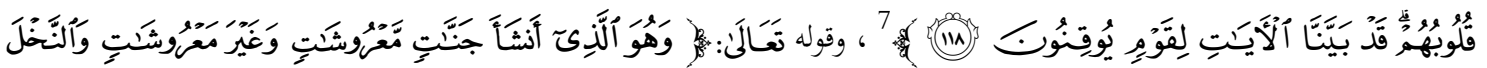

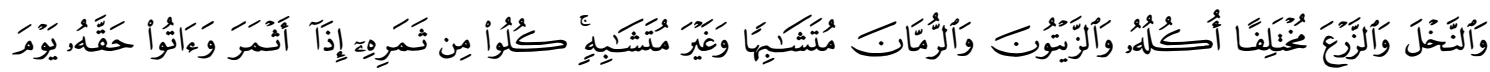

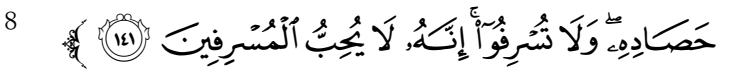

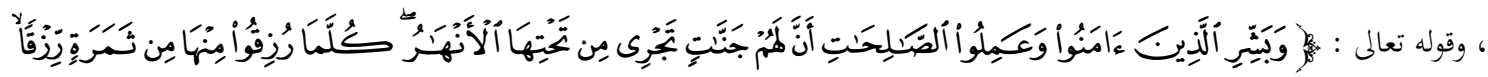

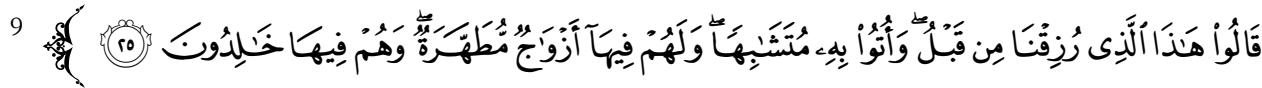

$$
\begin{aligned}
& \text { مما سبق عرضه من التعاريف نلاحظ أن المتشابه عند أهل اللغة يدور مفهومه حول معينيين : } \\
& \text { الأول : معنى التماثل والمساومة والآخر : معنى الاشكال او الالتباس والخط. }
\end{aligned}
$$

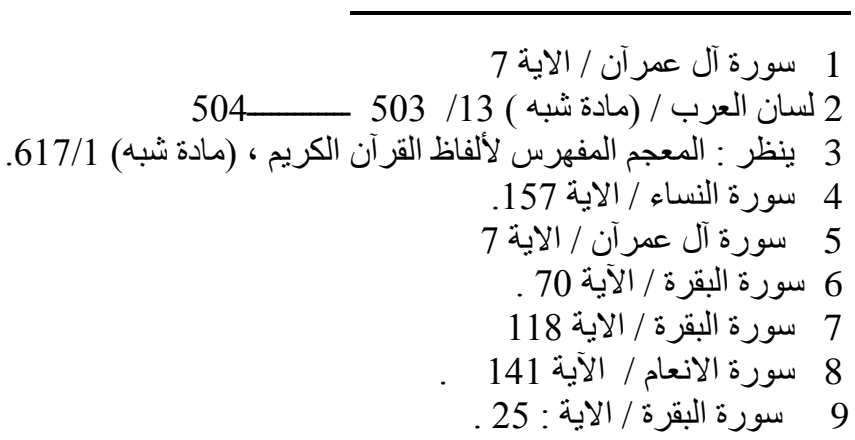




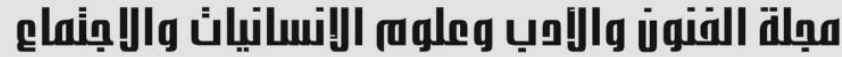

Journal of Arts, Literature, Humanities and Social Sciences \\ www.jalhss.com

1 لغة : ( اللفظ : اللام والفاء والظاء كلمة صحيحة تدل على طرح الشيء وغالب ذلك ان يكون من الفم .) الفيل وعلى هذا فسر الفيومي دلالة اللفظ فقال : لفظ البحر دآبة ،ألقاها الى الساحل ، ولفظت الارض الميت ، قذفته ، ولفظ بقول حسن ، تكلم به وتلفظ به .) 22، واللفظ واحد الألفاظ ، بمعنى المفعول ، أي :الملفوظ وهو في الاصل مصدر ، يقال : لفظ ، يلفظ ، لفظاً 3 ، ويف

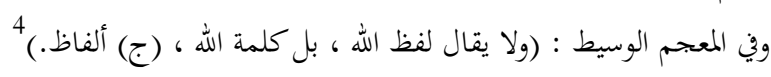
نلخص مما تقدم أن اللفظ مصدر للفعل (لفظ ) ، وما أشتق من الفعل يشترك مع المصدر فيما يدل عليه من معنى ، وللفعل معان متعددة لعل أشهرها ما يلفظ من الكلام والجمع ألفاظ ، وقد تنبه أصحاب المعجم الوسيط الى لفتة رائعة إذ قالوا : ولا يقال لفظ الله بل كلمة الله تعريف (توجيه المتشابه اللفظي ) اصطلاحما : لابد ان أبين ان المتشابه في القرآن الكريع يطلق على معنيين : الأول المتشابه الذي يقابل المحكم وقد أختلف العلماء في تعريف المحكم والمتشابه على أقوال عديدة منها :

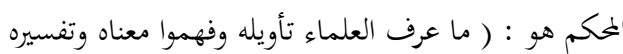

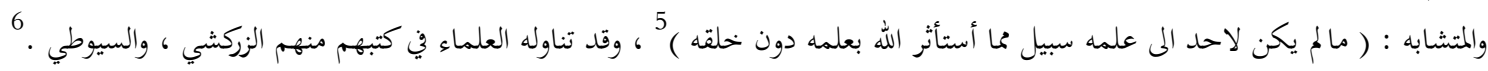

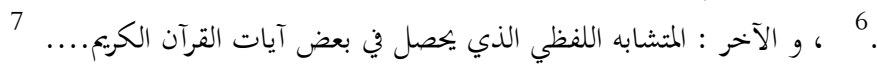

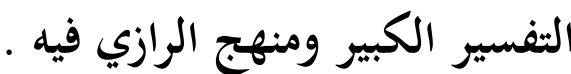

أجمعت المصادر التي ترجمت حياة الرازي أن له كتابا في تفسير القرآن وعدوه من جملة مصنفاته8 ، وعُرف باسم التفسير الكبير 9 ، ويقع تفسيره في أثنين وثلاثين جزءا وفقا لطبعة بيروت لسنة (1420هـ) ، وقد أشار الى تسميته في بعض كتبه ، من ذلك قوله في كتابه ( المعالم

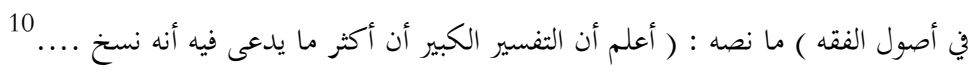

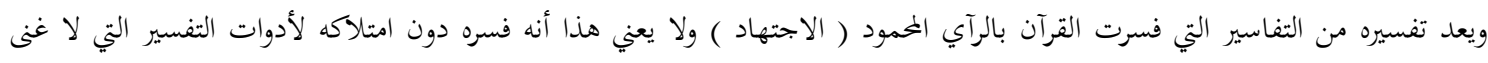

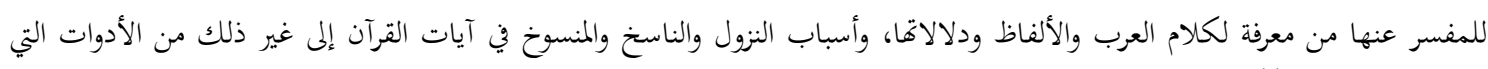
بكتاج اليها المفسر. 11

1

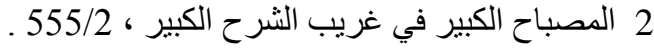

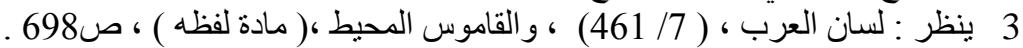
4 5

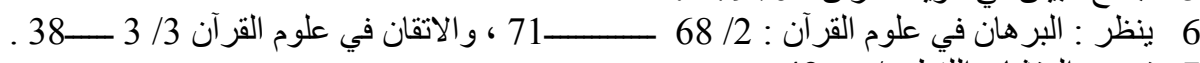

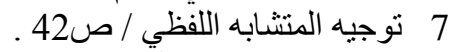

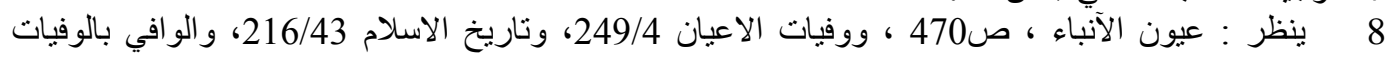
$.179 / 4$

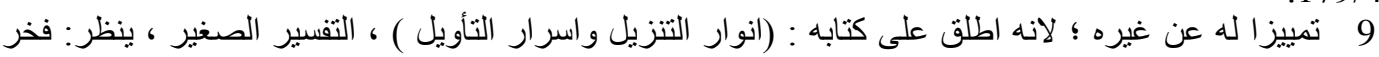

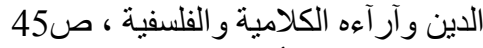

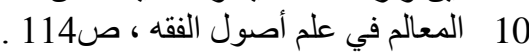

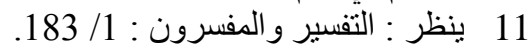




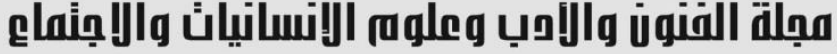

Journal of Arts, Literature, Humanities and Social Sciences www.jalhss.com

\section{المبحث الثاني / بين بدي السورة}

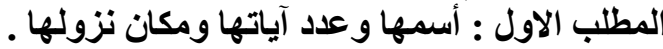

سميت سورة الكهف بهذا الاسم لما فيها من المعجزة الربانية في تلك القصة الكهات العجيبة الغريبة ، قصة اصحاب الكهف . 1.

و عدد آياتها عشرة ومآئة بلا خلاف بين العلماء .2

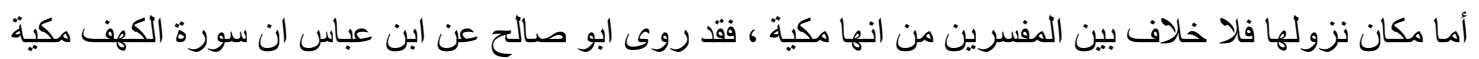

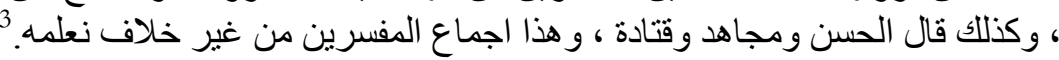

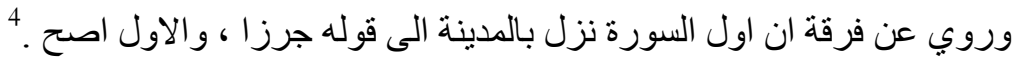

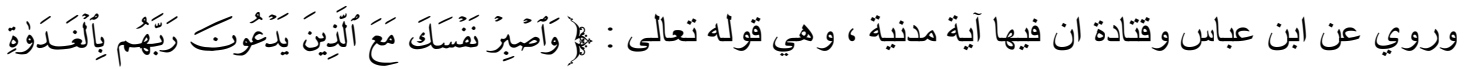

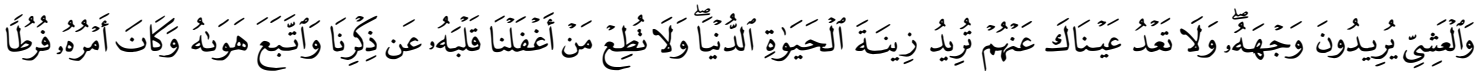

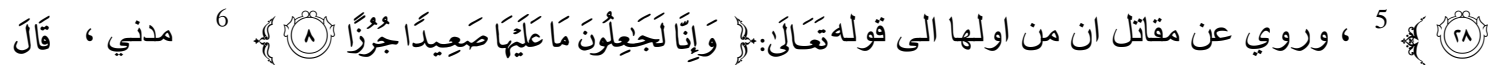

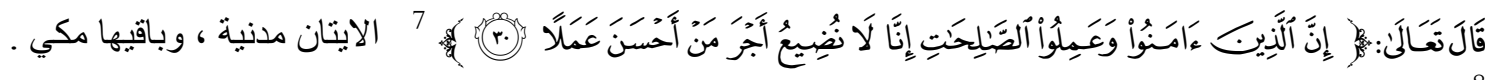

من خلال ما تقدم من ذكر اقوال العلماء والمفسرين في مكان نزول سورة الكهف يتبين لنا ان السورئ السورة مكية بالاجماع ، الا قوله تعالى : ( واصبر نفسك ...) حيث ذكر المفسرين انها نزلت في المدينة ، وذكروا لذللك سبيا

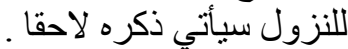

\section{المطلب الثاني / سبب نزولها} إن معرفة سبب النزول كما يقول العلماء مهم لمعرفة معنى الاية والاحكام التي تضمنتها ، وقد بين العلماء ان سبب النزول هو : ما نزلت الاية او الايات متحدثة عنه ومبينة لحكمه ايام وقوعه . 9 إن والمعنى انه حادثة وقعت في زمن النبي صلى الله عليه وسلم ،او سؤال وجه اليه إفنزلت الاية او الايات من الله سبحانه وتعالى في بيان ما يتصل

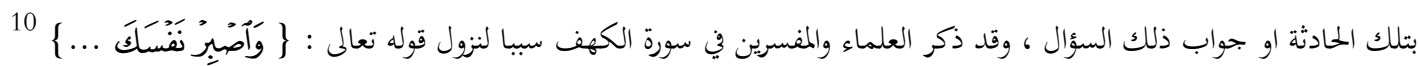
قال الواحدي في اسباب النزول : ( عن سلمان الفارسي قال : (ر جاءت المؤلفة قلوبم الى رسول الله صلى الله عليه وسلم ، عيينه بن حصن ، والاقرع ابن حابس ، وذوهم ،فقالوا : يا رسول الله ، انك لو جلست في صدر المحلس ، ونخيت عن هولاء وارواح جباهم يعنون سلمان وابو ذر وفقراء المسلمين ، وكانت عليهم جباب الصوف ولم يكن عليهم غيرها ، فجلسنا اليك وحدثناك ، واخذنا عنك ؛ فانزل الله :

$$
1 \text { ينظر : ينظر : المصدر التفاسير } 170 / 2
$$

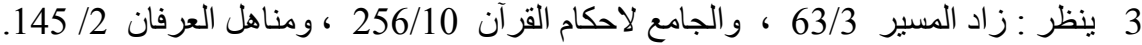

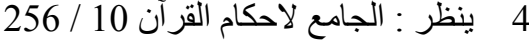

$$
\begin{aligned}
& 5 \\
& 6 \text { سورة الكهف/ الآية } 8 . \\
& 7 \text { سورة الكهف/ الاية } 30
\end{aligned}
$$

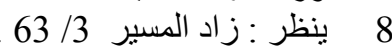

$$
\begin{aligned}
& 9 \\
& 10 \text { سورة الكهف / الاية } 28
\end{aligned}
$$




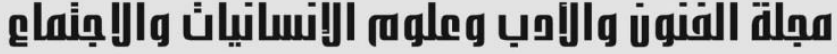

Journal of Arts, Literature, Humanities and Social Sciences www.jalhss.com

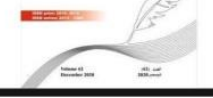

\section{Volume (63) January 2021}

يناير 2021

العدد (63)

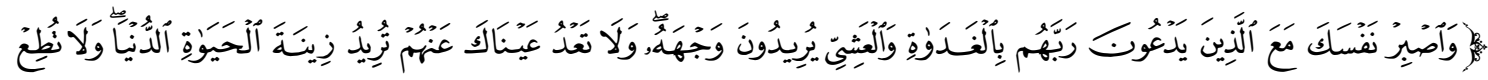

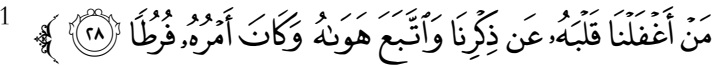

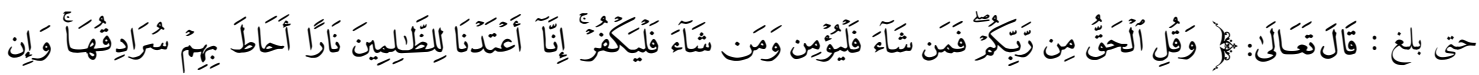

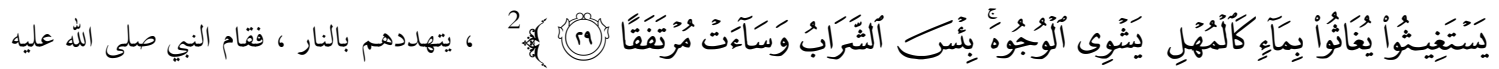

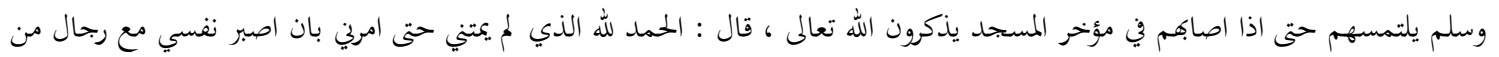

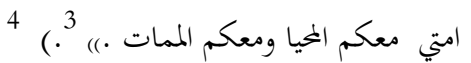

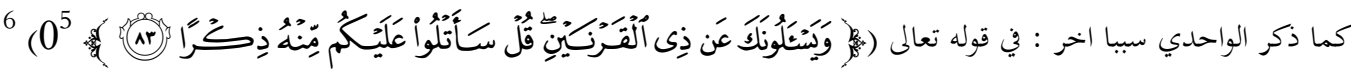

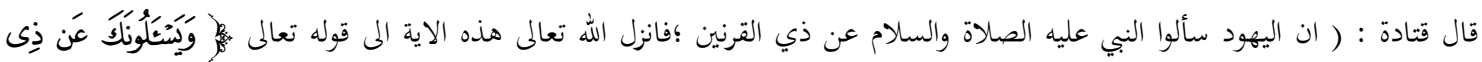

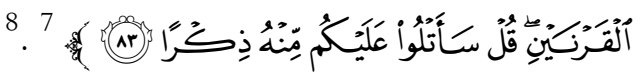

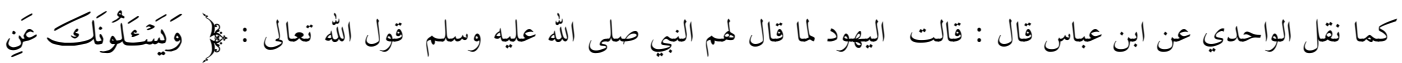

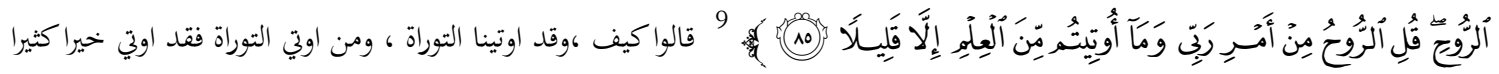

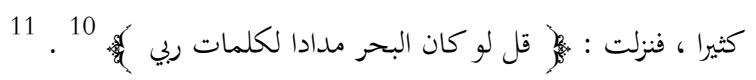

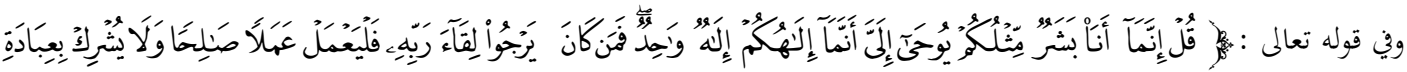

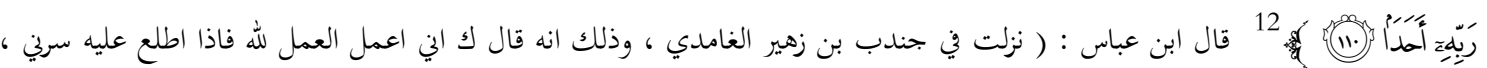

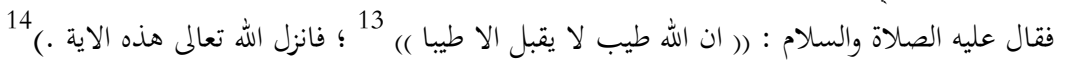

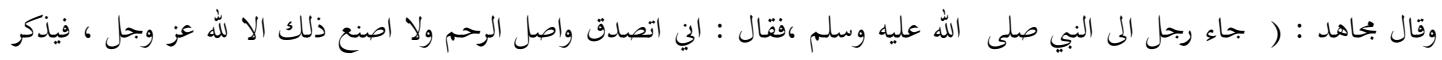

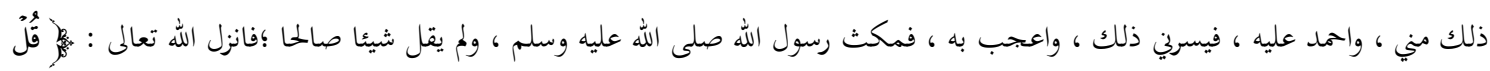

$$
\begin{aligned}
& \text { 28: الائ } 1 \\
& 2 \\
& 3 \text { شعب الايمان للبيهقي / باب الزهد هد وقصر الامل ،10012 رقم الحديث ، 99/13. } \\
& 4 \\
& \text { 83: } 5 \\
& 6 \\
& \text { ( } 78 \\
& 8 \text { ينظر : اسباب النزول / } 152 \\
& 9 \\
& 10 \text { سورة الكهف / الاية } 109 \\
& 11 \text { ينظر: اسباب النزول ل/ } 152 \\
& 12 \text { سورة الكهف / الاية } 110
\end{aligned}
$$

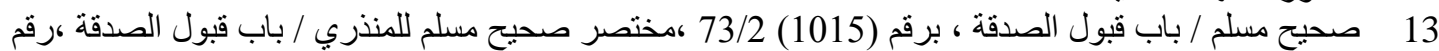

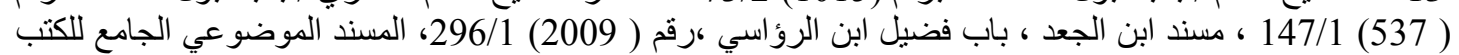




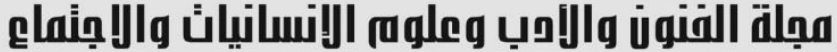

Journal of Arts, Literature, Humanities and Social Sciences www.jalhss.com

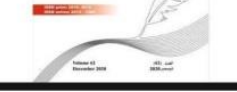

\section{Volume (63) January 2021}

يناير 2021

العدد (63)

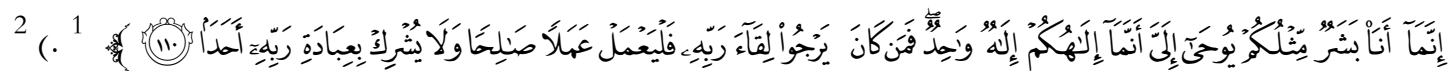

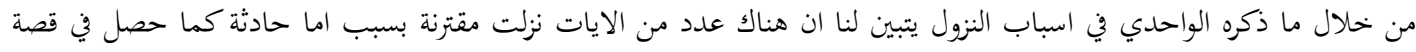
المؤلفة قلوبهم ، وفقراء الصحابة ، او اجابة على سؤال اليهود عند سؤالهم عن ذي القرنين .

المطلب الثالث / موضوعاتها :

تعرضت السورة لثلاث قصص من روائع قصص القرآن في سبيل تقرير اهدافها الاساسية لتثبيت العقيدة والايمان بعظمة الله جل وعلا ، وهذه القصص هي . 1/ قصة اصحاب الكهف : وهي قصة للتضحية بالنفس في سبيل الدعوة والعقيدة ، وهم الفتية المؤمنون الذين خرجوا من بلادهم فارين

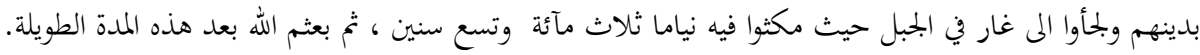

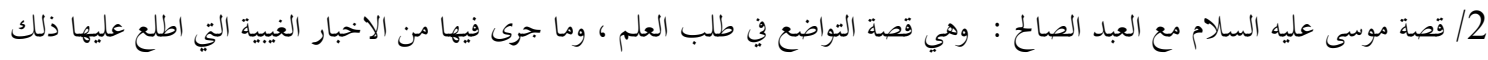

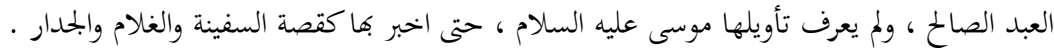

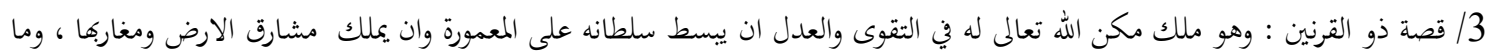
كان من امره في بناء السد العظيم . مان. كما استخدمت السورة في سبيل الوصول الم الصدق في القصص الثلاث ثلاث امثلة واقعية ؛ لبيان ان الحق لا يرتبط بكثرة المال والسلطان ،

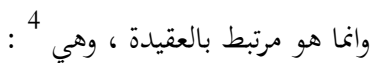
المثال الاول / الغني المزهو بماله والفقير المعتز بعقيدته ودينه كان هذا في قصة اصحاب المنتين.

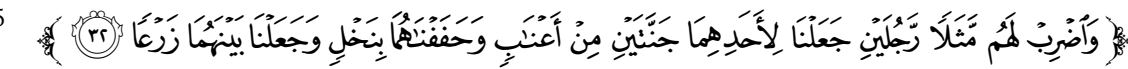

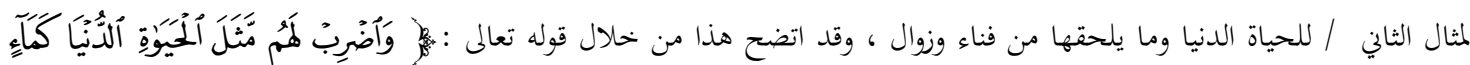

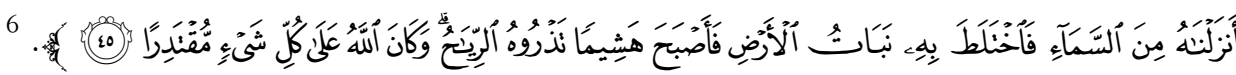

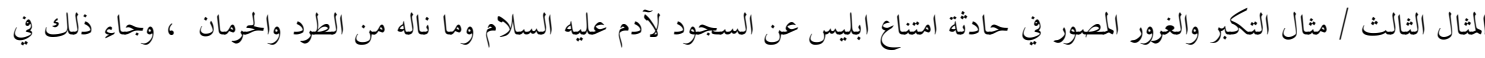

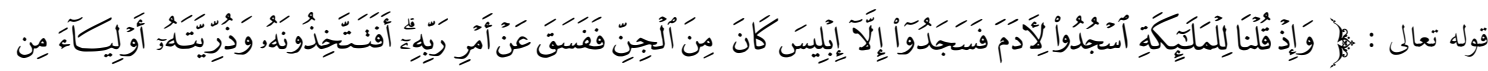

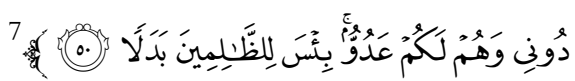
وكل هذه القصص والامثال جاءت ؛لاجل العظة والاعتبار والله اعلم لمدان.

$$
\text { المطلب الرابع / فضل السورة النورة }
$$

ذكر العلماء والمفسرين أحاديث كثيرة في فضل السورة صح بعضها وضعف البعض الاخر منها ،ولا نذكر هنا الا ما صح من احاديث في

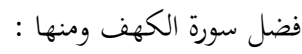
1 / ما رواه الامام مسلم في صحيحه عن ابي الدرداء رضي الله عنه ( ان النبي صلى الله عليه وسلم قال : (ر من حفظ عشرة ايات من سورة

$$
\begin{aligned}
& 110 \text { 110 سورة الكهف / الاية } 153 \\
& 2 \\
& 3 \text { ينظر :صفوة التفاسير 170/2 } \\
& 4 \\
& 5 \\
& 6 \text { سورة الكهف / الآية } 45 \\
& 7 \text { سورة الكهف / الآية } 50
\end{aligned}
$$




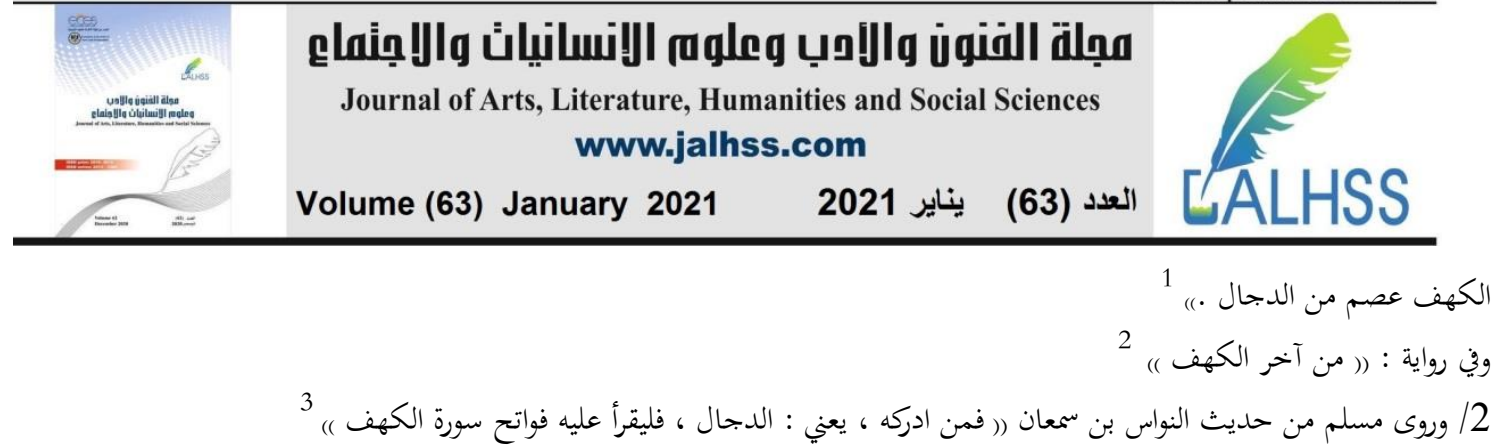

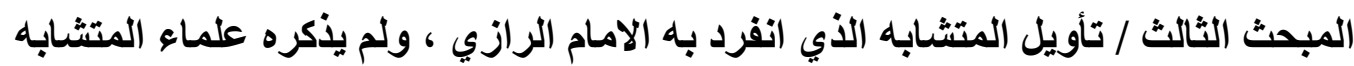

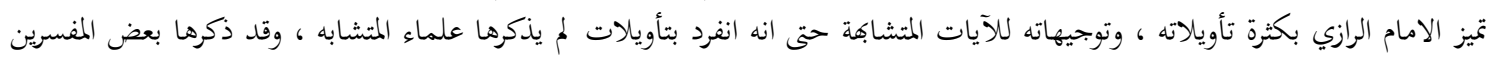

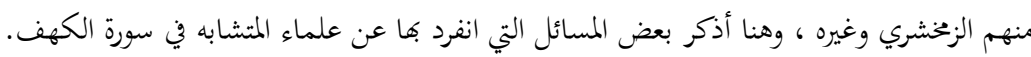

| المسألة الأولى | (n)

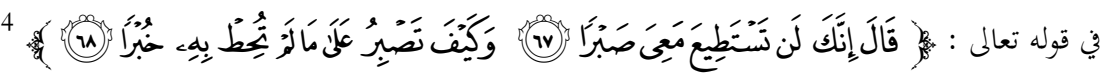
قال الامام الرازي في معرض حديثه عن تفسير الاية : ان الاستطاعة لا تحصل قبل الفعل ،قالوال لوالو كانت الاستطاعة على الفعل حاصلة قبل الفيل

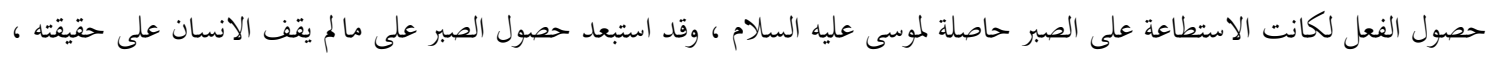
ولو كانت الاستطاعة قبل الفعل لكانت القدرة على العلم حاصلة قبل حصول ذلك الك العلم. وقد خالف صاحب الكشاف ما ذهب اليه الرازي حيث قال : ( نفي استطاعة الصبر على وجه التأكيد كأها من ما لا يصح ولا يستقيم ،

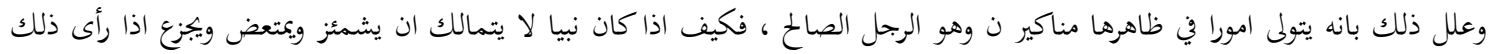
ويأخذ بالانكار .) خلاصة المسألة : ان الفعل لا يكصل قبل وقوعه لكن نفي الخضر للأستطاعة بناءا على مقدمات معروفة ، وهي ان الانبياء عليهم الصلاة

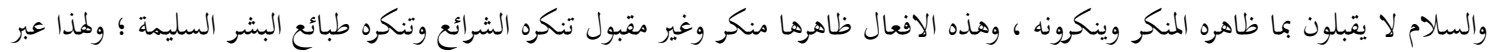

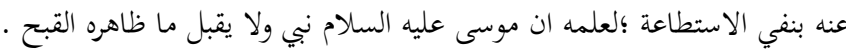

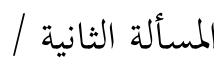

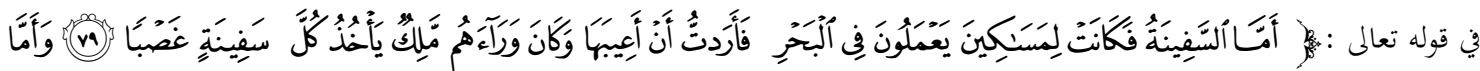

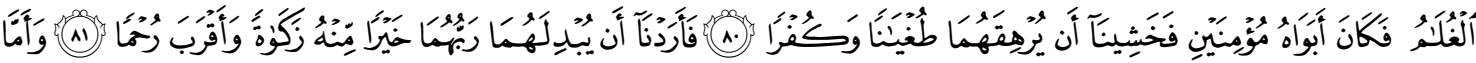

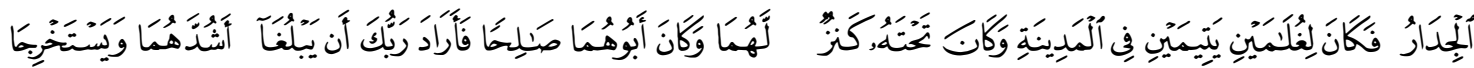

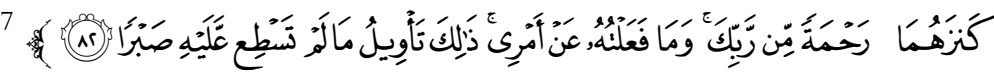

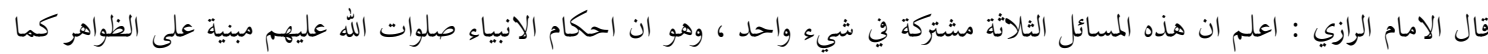

1 ، صحيح مسلم / باب فضل سورة الكهف ، رقم 809، 555/1 ، و المستدرك على الصحيحين /باب تفسير سورة الكهف

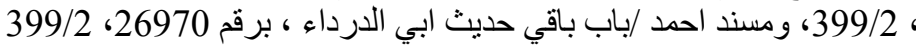

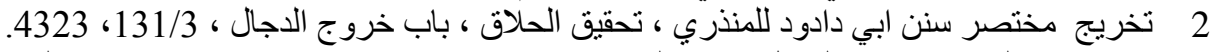

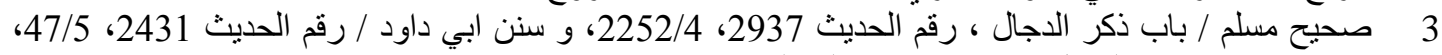

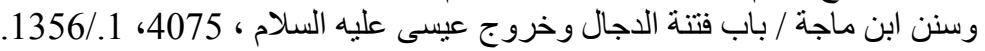
4 5 6 7 


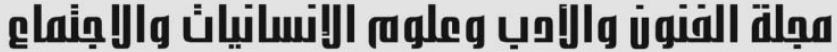

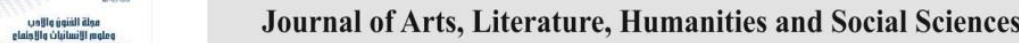 www.jalhss.com}

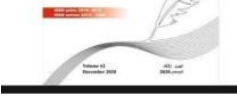

Volume (63) January 2021

يناير 2021

(63) (العدد)

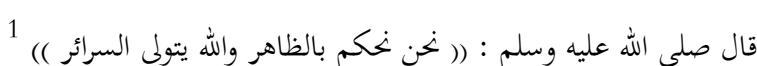
وهذا العالم في قصة موسى ماكانت احكامه مبنية على ظواهر الامور ، بل كانت مبنية على الاسباب الحقيقية الواقعة في نفس الامر ؛وذلك لان الظاهر يحرم التصرف في اموال الناس وفي ارواحهم فليس هناك من سبب ظاهر يبيح ذلك التصرف لان تخريق السفينة تنقيص ملك انسان من غير سبب ظاهر ، وقتل الغلام تفويت لنفس معصومة من غير سبب ظاهر ، واقامة الجحدار في المسألة الثالثلة تحمل للتعب والمشقة من غير سبب ظاهر ، وفي كل هذه المسائل الثلاث ليس حكم العالم فيها مبني على اسباب ظاهرة المعلومة بل كان ذلك الحكم مبني على اسباب حقيقية في نفس الامر وهذا يدل على ان ذلك العالم قد اعطاه الله قوة عقلية قدر بها ان يشرف بواطن الامور ويطلع بها على حقائق الاشياء

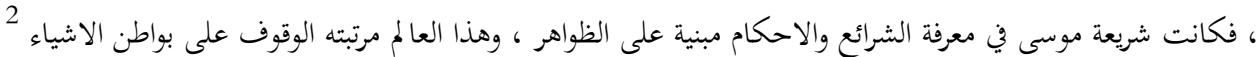
وخلاصة المسألة : أن الانبياء مأمورون بأخذ بظواهر الامور والله سبحانه وتعالى يتولى السرائر ؛ ولهذا أنكر موسى عليه السلام ما ظاهره القبح ، بينما اخذ العبد الصالح ببواطن الامور وما علمه الله سبحانه وتعالى ويظهر هذا جلياً عند تفسيره للحوادث الثلاث ، يتبين لنا انما كانت لحكمة ربانية مبنية على المصلحة المتحققة من الفعل ، والله تعالى اعلم .

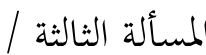

33 في قوله تعالى 3.

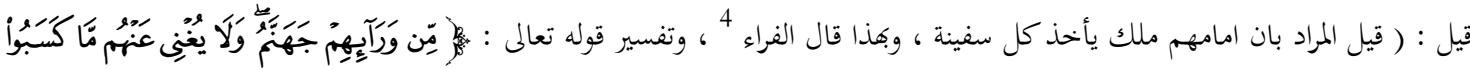

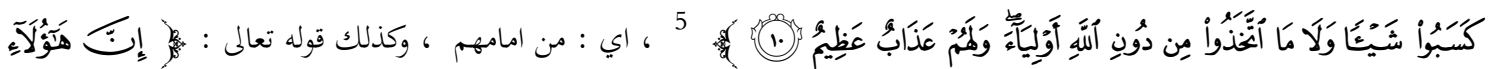

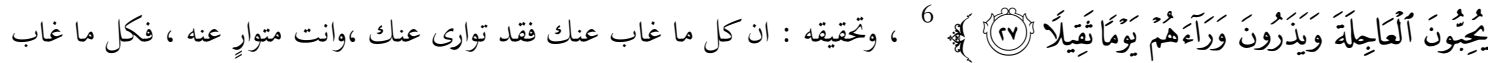

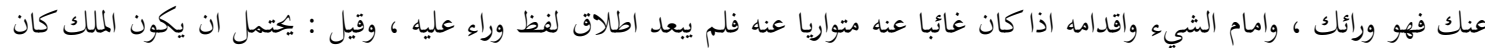

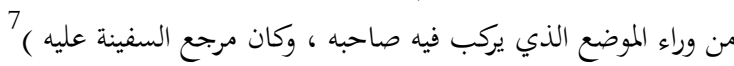

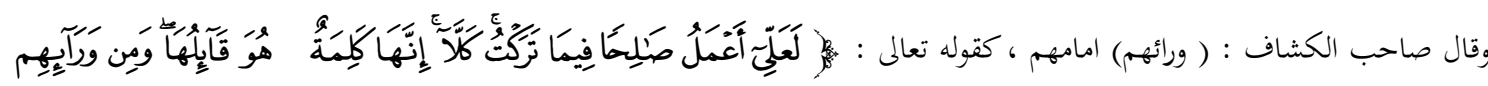

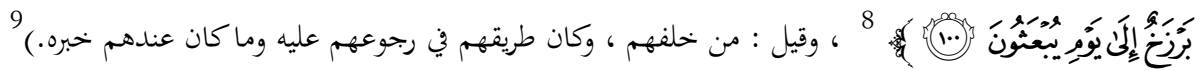

وخحاصة المسألة : أن الرازي ووافقه الزخشري ذهبا المى ان هناك توجيهان في المسألة ، الاول و هو الارجح

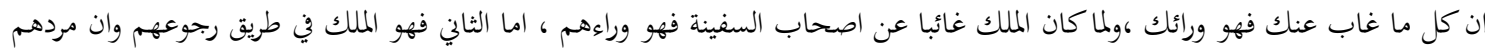

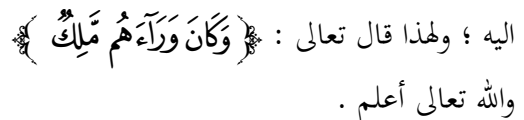

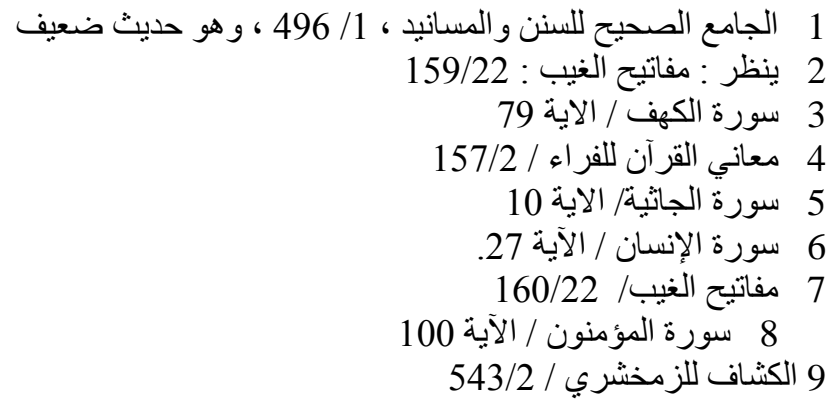




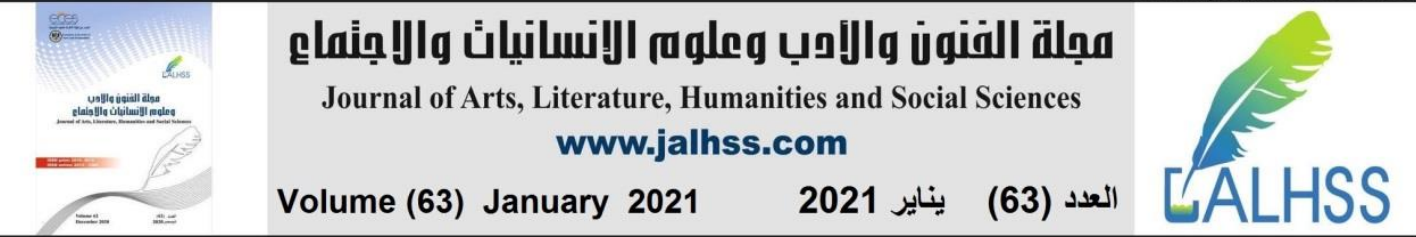

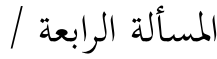

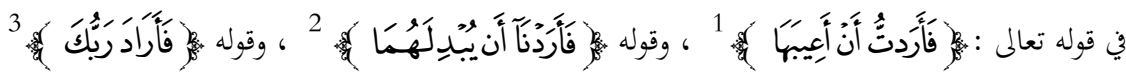

$$
\begin{aligned}
& \text { حيث اختلفت الاضافات في هذه الارادات الثلاث مع ان جميعها في قصة واحدة وفعل واحد }
\end{aligned}
$$

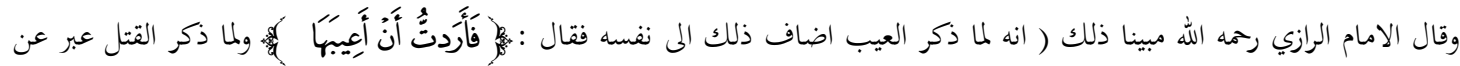

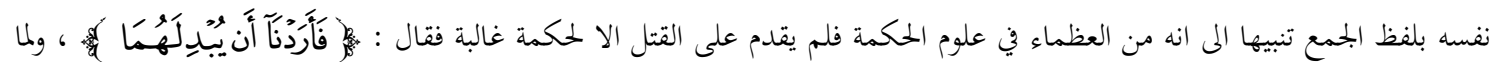
ذكر رعاية مصالح اليتيمين لاجل صلاح ابيهما اضافه الى الله تعالى ؛ لانه المتكفل بمصالح الابناء ؛لرعاية حق الآباء ليس الا الله سبحانه

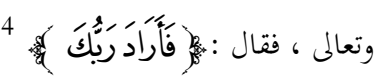

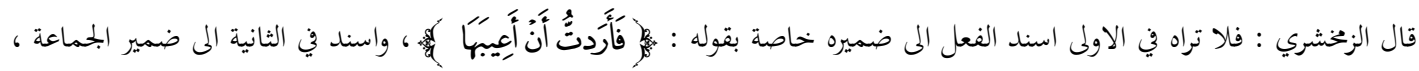

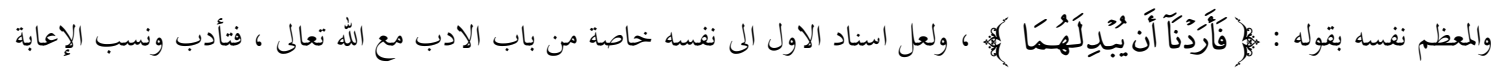
اللى نفسه ، أما اسناد الثاني الى الضمير المذكور فالظاهر من باب انه من خواص إنهإ الملك : أمرنا بكذا ، او دبرنا كذا ، ويعنون انما أمر الملك

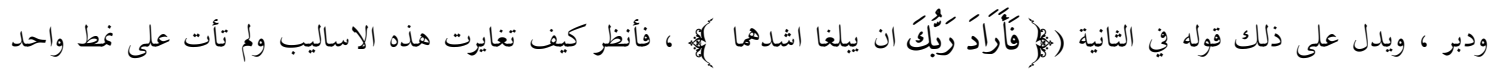

$$
\text { مكرر يمجه السمع وينبو عنها ، ثم انطوت هذه المخالفة على رعاية الاسرار المذكورة . }
$$

وخلاصة المسألة أن العبد الصالح أسند الفعل في عيب السفينة الى نفسه ادبا مع الله تعالى واستعمل صيغة الجمع في المسألة الثانية وكانه

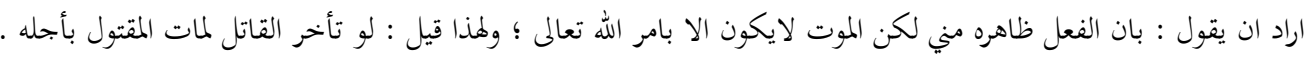

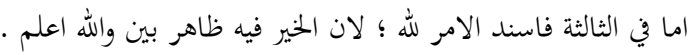

\section{المبحث الرابع /تأويل المتشابه الأي ذكره علماء المتشابه .} ذكرتُ في المبحثِ السابق المسائل التي انفرد بها الرازي وهنا نذكر المسائل التي ذكرها الرازي ، وقد ذكرها علماء التأويل منهم الاسكافي ،

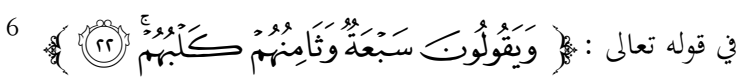
ذكروا في فائدة الواو في قوله ( وثامنهم كلبهم ) وجوها: 1/ ما ذكرنا انه يدل على أن هذا القول اولى من سائر الاقوال.

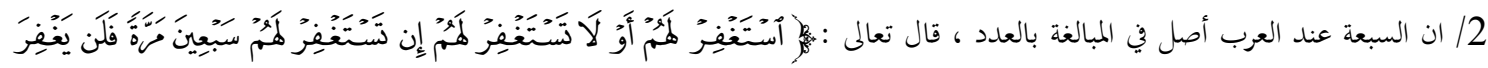




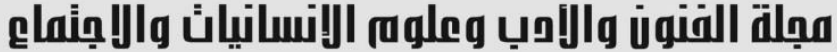

Journal of Arts, Literature, Humanities and Social Sciences

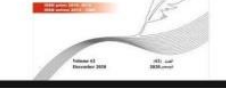

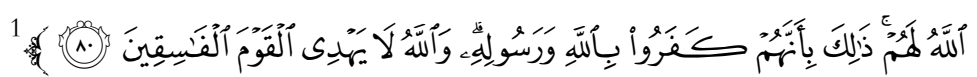

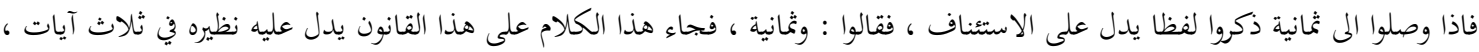

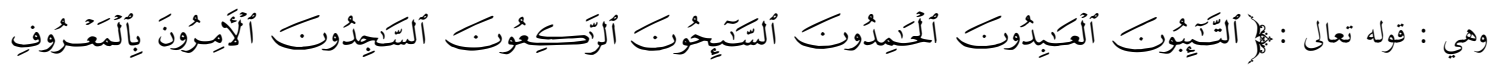

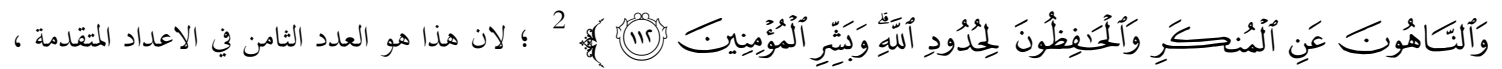

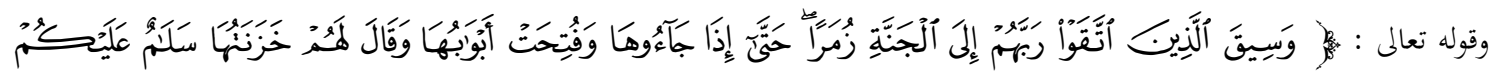

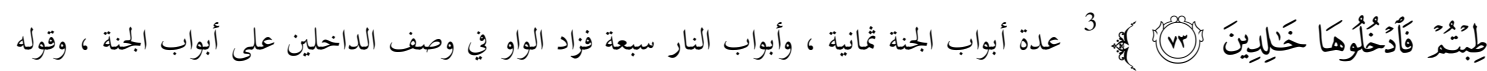

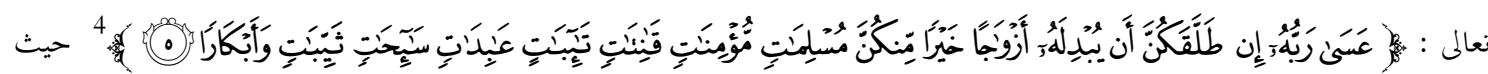
انها العدد الثامن فيما تقدم .

قال الغرناطي في ملاك التأويل : فيسأل عن أختصاص واو ثمانية ولم ترد بالجملة من قوله تعالى : ( وثامنهم كلبهم ) صفة للفكرة قبلها6

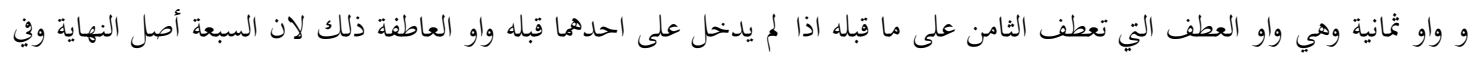

قال الزخشري فيها ( هي الواو التي تدخل على الجملة الواقعة صفة للنكرة كما تدخل حالا عن لمعرفة في نخو قولك جاءين رجل ومعه آخر

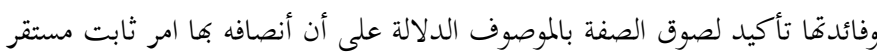

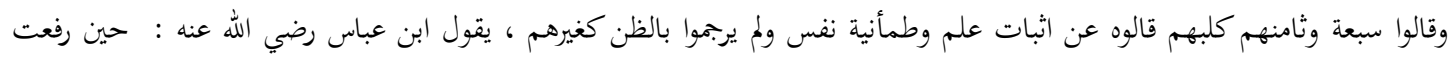

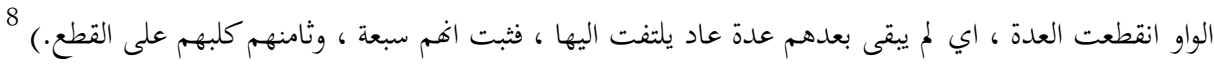

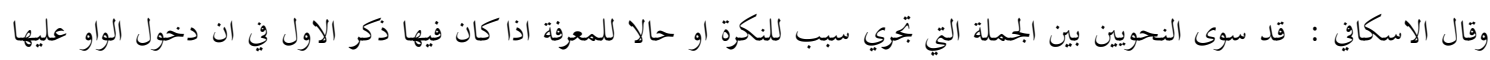
9 وحذفها منها جائزان قال الزجاج ( دخول الواو ها هنا واخراجها من الاول واحد )

واضاف الاسكافي ان فائدة زيادة الواو من وجهين . 11 ان الاول / ان في قوله ثلاثة رابعهم ، وقوله خمسة سادسهم ، في كل منها بعدها ذكر قول آخر ، أما في قوله سبعة وثامنهم فاهما انتهت فيها العدة وانقطعت بها.

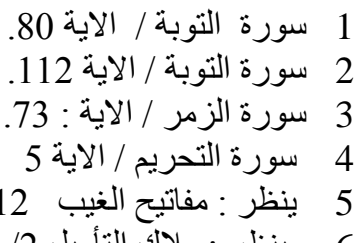

6

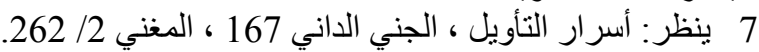

525/1: 8

$918 / 1$ : 9

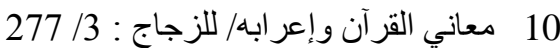

11 ينظر درة التنزيل : 10 / 820 


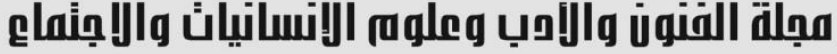

Journal of Arts, Literature, Humanities and Social Sciences www.jalhss.com

\section{Volume (63) January 2021}

يناير 2021

(63) (العدد)

الثاني / ان السبعة لما كانت اصلا للنهاية من تركيب العدد لان اصل الجمع واحد ، والواحد فرد ، والتركيب أن تضم فردا الى فرد فيصيران

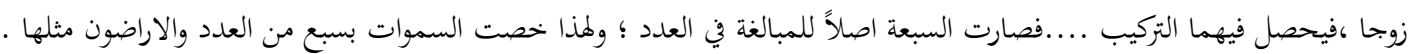

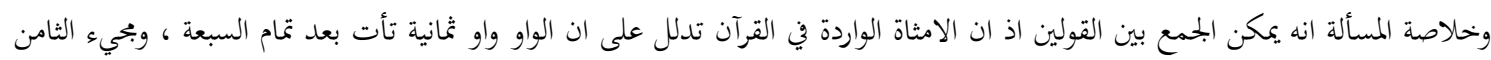

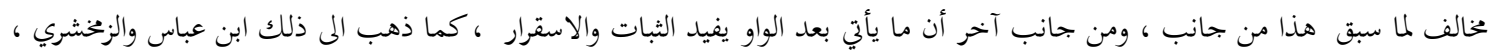
اي ان الارقام السابقة الثلاثة والاربعة والخمسة والستة كان الظن هو الغالب فيها ، اما في السبعة والثمانية فأصبح العدد يقينيا وثابتا .

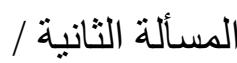

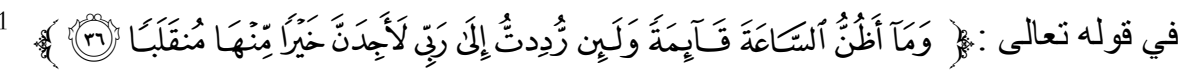

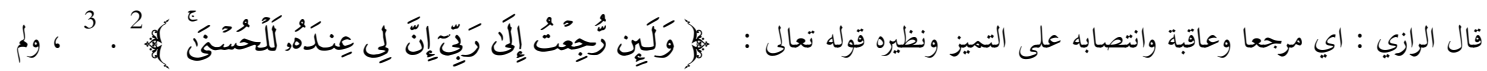

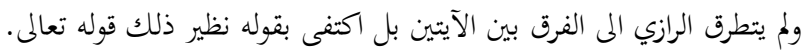

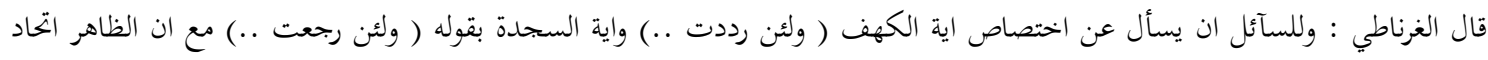

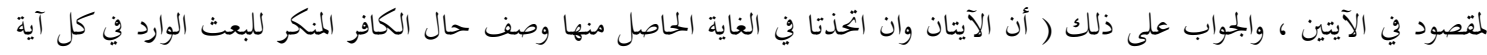

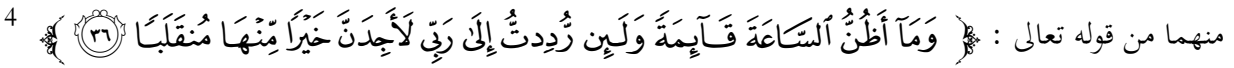
فإن اية الكهف منهما اقوى تعريفا يبعد الكافر المضروب به المثال عن حال الايمان ، اما اية السجدة فصالحة لاتصاف الكافر والمؤمن بالحال

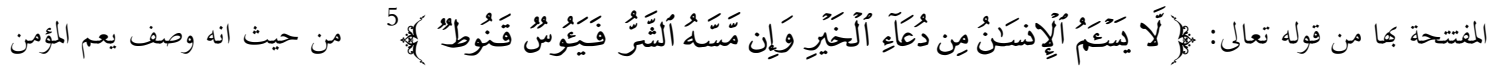
والكافر (j) فيما ذهب الاسكافي الى القول مما تقدم وصف الجنتين التين حوتا مراده واشتملت على ما اراده وتقديره فيها اغما يدومان له ؛ لهذا قال: (

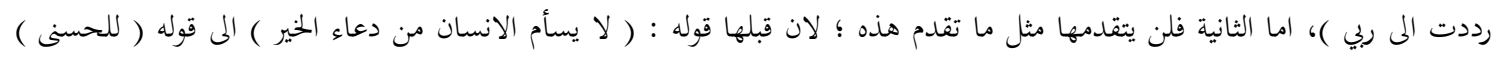

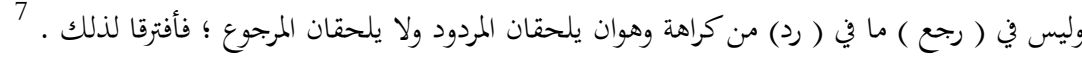

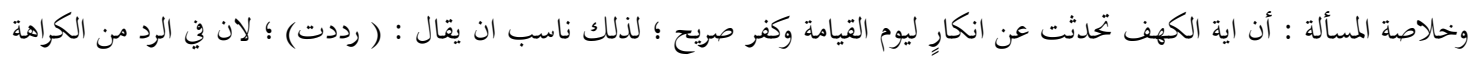

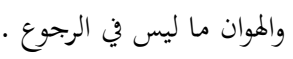
أما الاية التي في سورة فصلت ، فتحدثت عن الانسان بشكل عام مؤمنه وكافره ، فناسب ان يقال : (رجعت) والله اعلم | المسألة الثالثة الثة الثي لمرة

،

\begin{tabular}{|c|c|}
\hline & سورة الكهف / الاية 36 \\
\hline الاية 50 & سورة السجدة / جز ع من ا \\
\hline & مفاتيح الغيب : 125/21 \\
\hline & سورة الكهف / الاية 36 \\
\hline & سورة فصلت / الاية49 \\
\hline & ملاك التأويل :644/2. \\
\hline 826/1: & ينظر : درة التنزيل للأسكافي \\
\hline & سورة الكهف / الاية 71 \\
\hline
\end{tabular}




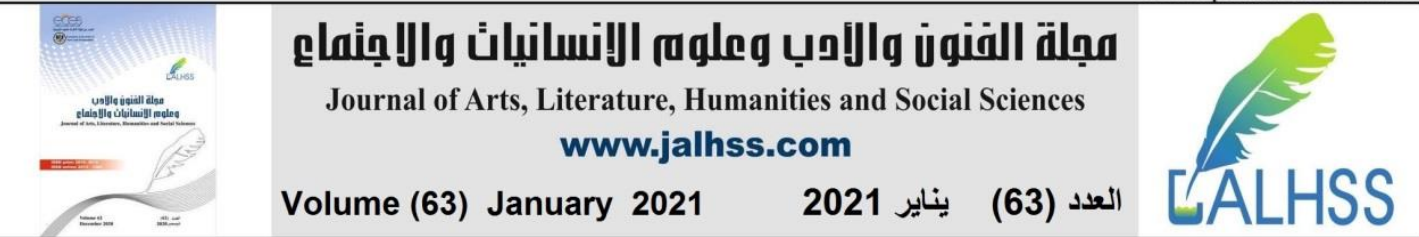

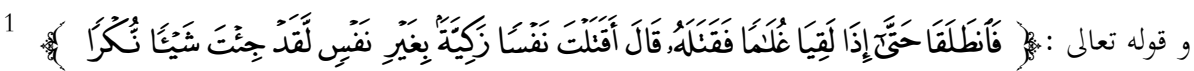

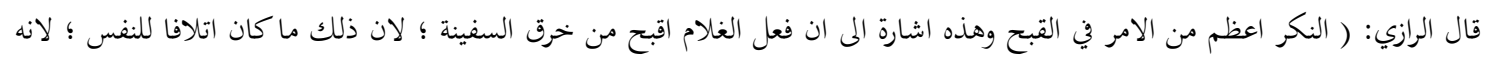

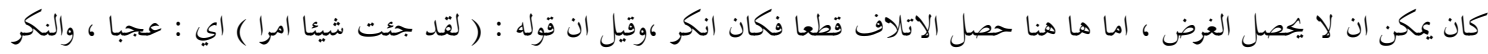

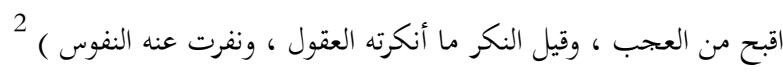

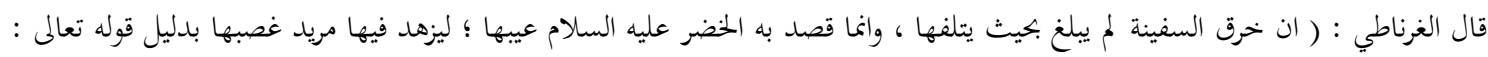

33

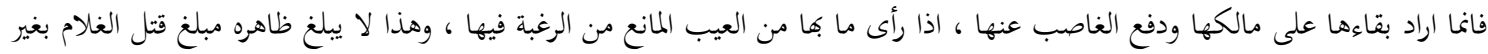

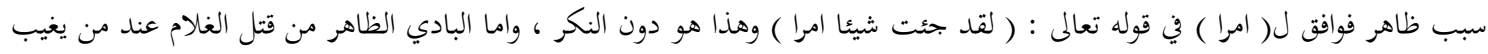

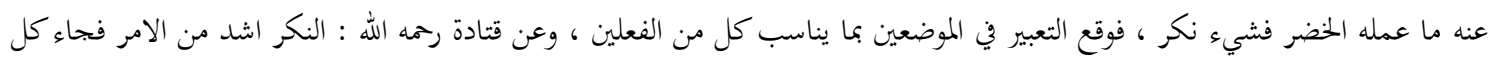

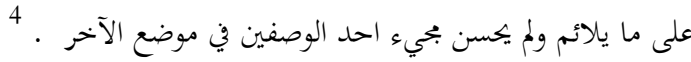
وذهب الزعشري الى القول ان النكر اقل من الامر ؛ لان قتل نفس واحدة اهون من الغراق الهاق اهل السفينة ، وقيل معناه جئت شيئا انكر من

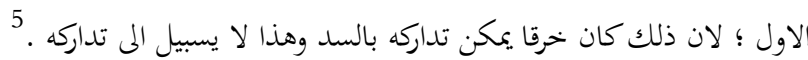

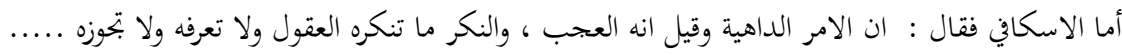

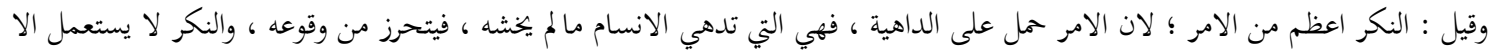

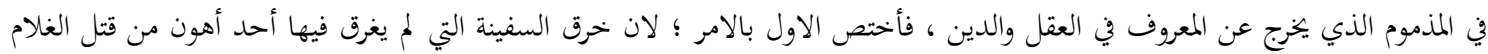

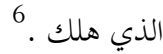
وخلاصة المسألة : ان الامر اهون من النكر إذ ان خرق السفينة من اجل انقاذها من الملك ، وان كان فيها عيب لم يصل الى حد الغرق ، اما قتل الغلام فهو اهلاك للنفس ، وتلاف لها ؛ ولذذا عبر عنه بالنكر ، وهذا ما ذهب اليه الرازي ، ووافقه الغرناطي فيما ذهب اليه ، والله تعالى

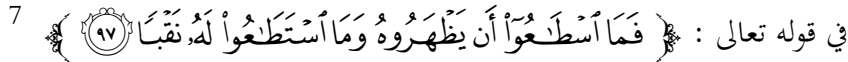

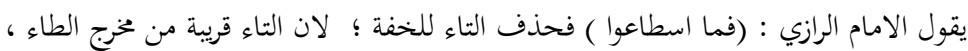
وقرء : ( فما اصطاعوا)

( ان يظهروه ) اي : ان يعلوه ، اي ما قدروا على الصعود عليه ؛ لاجل ارتفاعه وملاسته ، ولا على نقبه ؛ : لاجل صلابته وثخانته .

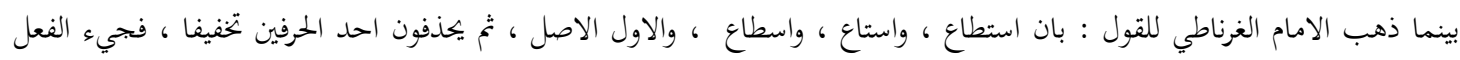




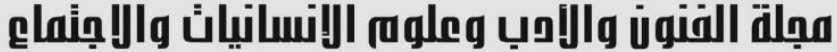

Journal of Arts, Literature, Humanities and Social Sciences www.jalhss.com

\section{Volume (63) January 2021}

يناير 2021

العدد (63) (2) (2)

الاول مخففا عند ارادة نفي قدرقم على الظهور على السد ، والصعود فوقه ، ثم جاء باصل الفعل مستوف الحروف عند نفي قدرتهم على نقبه وخرقه ، ولا شك ان الظهور عليه ايسر من النقب ، والنقب اشق عليهم ، واثقل ، فجيء بالفعل خفياً مع الاخف ، وجيء به تاما مستوفيا

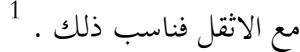

وقد ذهب الزخشري مذهب الرازي حيث قال : ما نصه: ( (فما اسطاعوا ) بحذف التاء للخفة ؛ لان التاء قريبة المخرج من الطاء ، وقريء : ( فما اصطاعوا ) بقلب السين صاد ..... ( ان يظهروه ) أي : ان يعلوه ، اي لا حيلة لهم فيه من صعود ، لارتفاعه وملاسته ، ولا

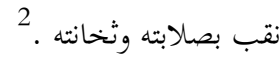

وذهب الاسكافي الى القول ( ان الثانية تعدت الى اسم وهو قوله عز وجل ( نقبا ) فخف متعلقها ،فاحتملت بأن يتم لفظها ، أما الاولى فان تعلق مكان مفعولما بأن والفعل بعدها ، وهي اربعة اشياء : إن ، والفعل ،والفاعل ، والمفعول الذي هو الهاء فثقل لفظ ( استطاعوا ) وكان

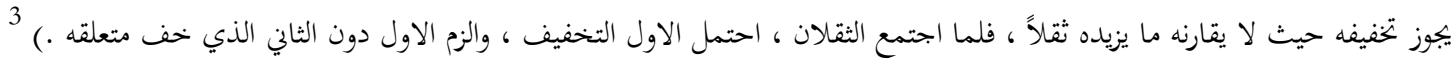
وخلاصة المسألة : أن ما ذهب اليه الغرناطي هو الانسب ، والله اعلم ، حيث ان الظهور على السد اهون واخف فناسب ان يقال : ( فما لهال

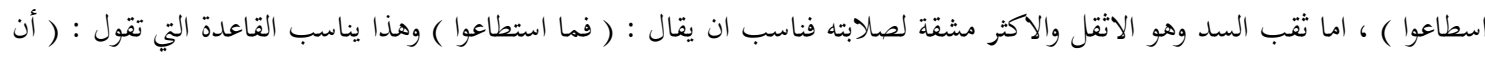

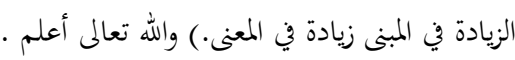

الخاتمة

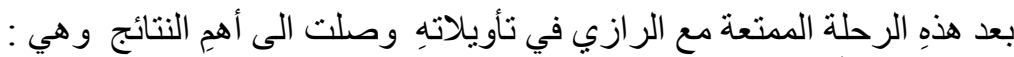

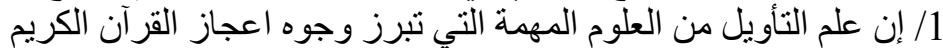

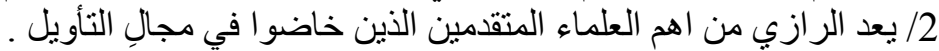

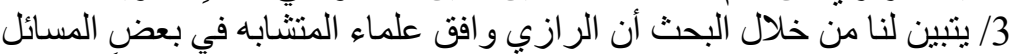

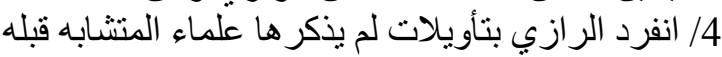

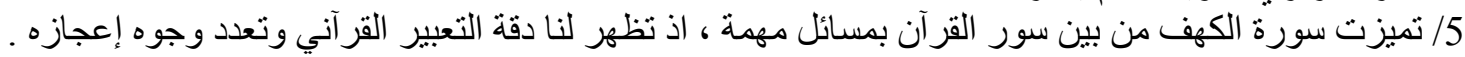

التوصيات

1/ ضرورة اهتمام الباحثين بتأويل المتنشابه و الخوض في في غماره

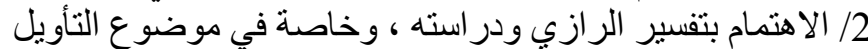

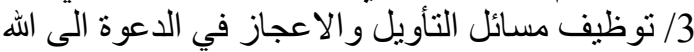

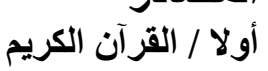
1/ الاتقان في علوم القرآن / آن التيد الرحمن بن ابي بكر جلال الدين السيوطي (ت 911ه)تح:محمد ابو الفضل ابر اهيم

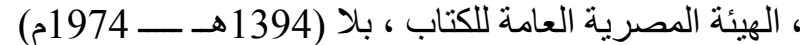
2/ اسباب النزول / للامام ابي الحسن علي بن احمد الواحدي النيسابوري ، مراجعة : سمر محمد ظاهر ، مؤسسة الكتب الثقافية 3/ أنوار التنزيل و أسرار التأويل/ الدين أبو سعيد عبد الله بن عمر بن محمد الثيرازي البيضاوي (المتوفى: 685هـ)

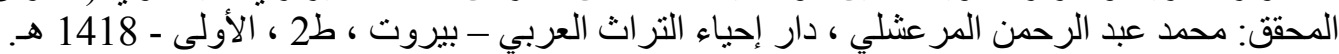

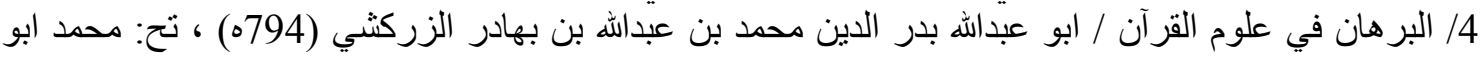




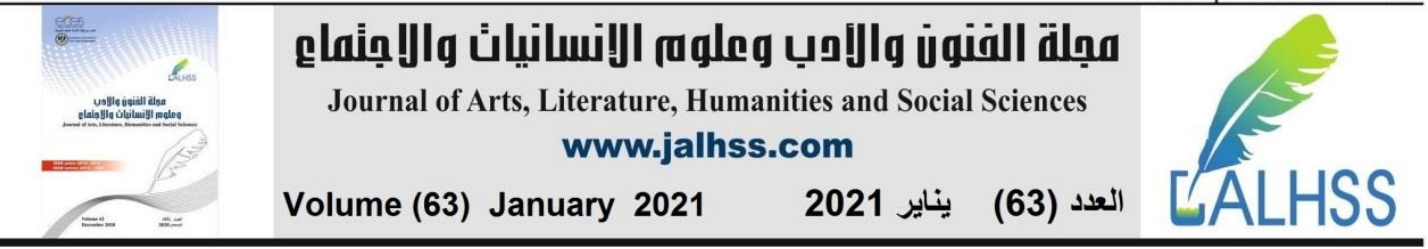

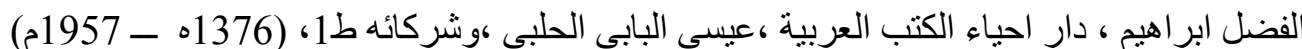

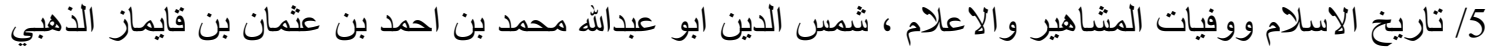

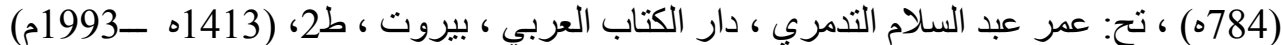

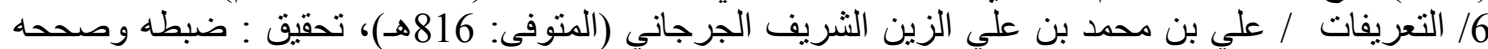

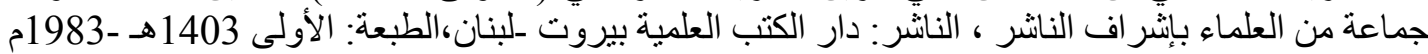

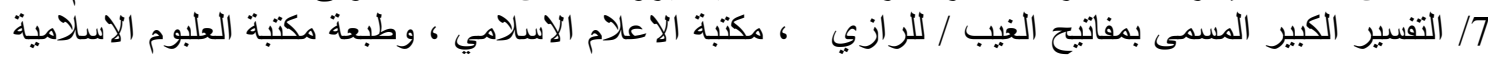

3. 1311

8/ التفسير و المفسرون / د.محمد السيد حسين الذهبي ، ت(1398ه)مكتبة وهبة ، القاهرة ، بلا ،د.ت.

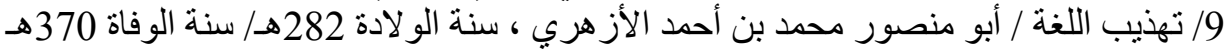

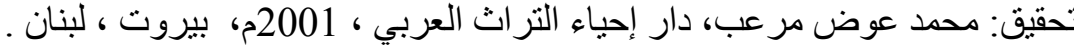

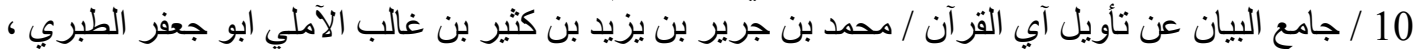

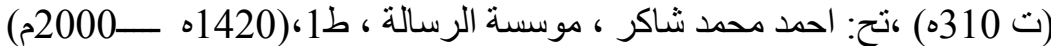
10/ الجامع الصحيح للسنن والمسانيد / صهيب عبد الجبار، عدد الأجزاء: 38، تاريخ النشر 15 - 8 - 2014

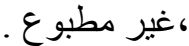

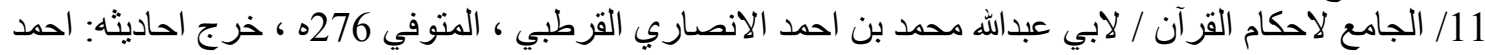

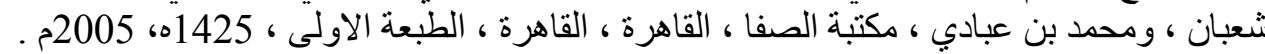

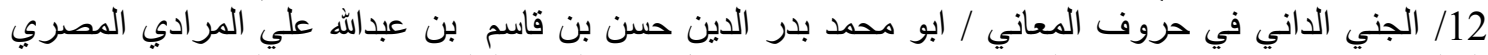

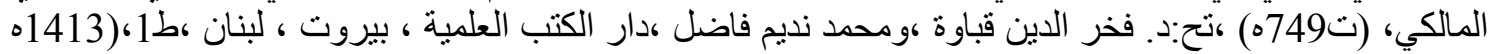

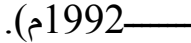

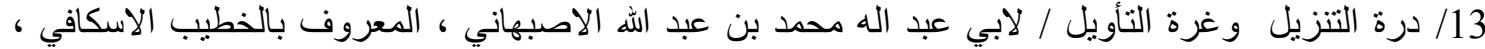

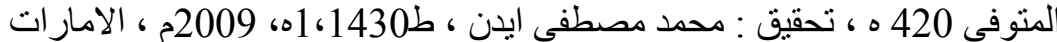

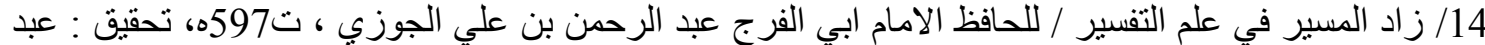

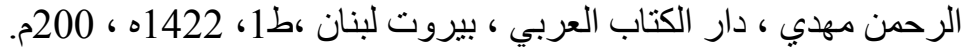

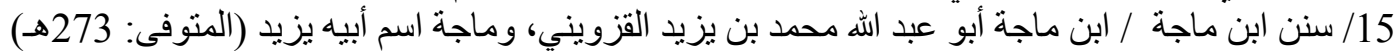

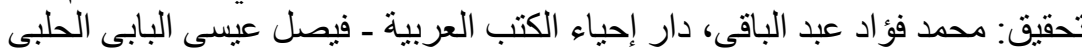

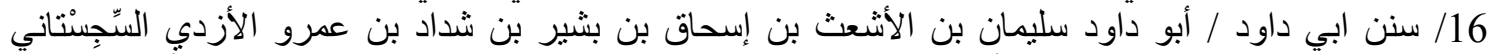

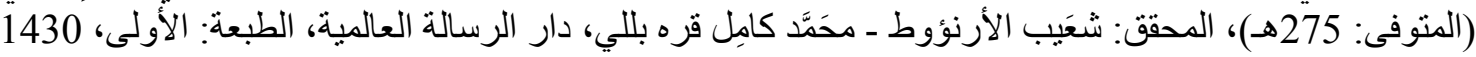

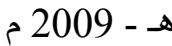

17/ شعب الايمان للبيهقي / أبو بكر أحمد بن الحسين بن علي بن عبد الله بن موسى الخسروجردي البيهقي (384. $(\rightarrow 458$ 18/ صحيح مسلم / مسلم بن الحجاج أبو الحسين القشيري النيسابوري، سنة الو لادة 206/ سنة الوفاة 261، تحقيق

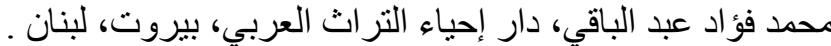

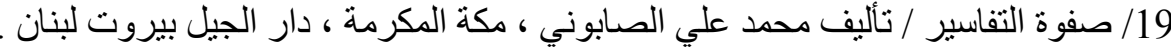

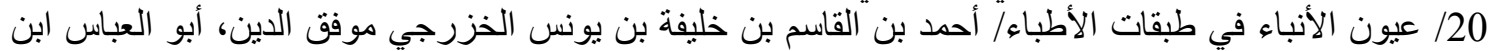

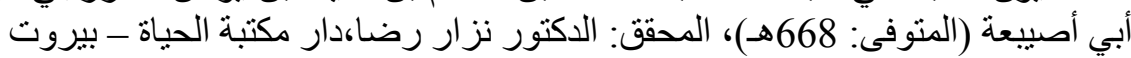

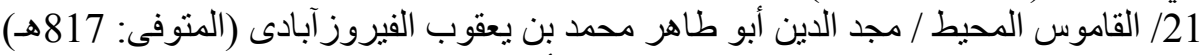

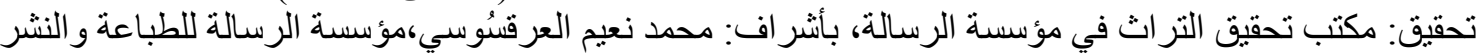

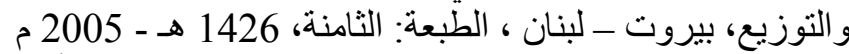

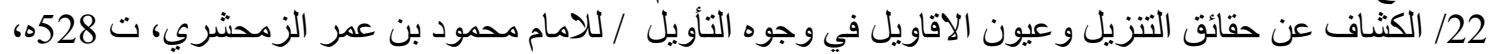

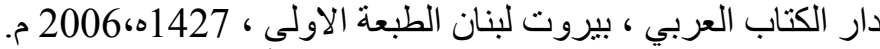
23/ لسان العرب / محمد بن مكرم بن على، أبو الفضل، جمال الكال الدين ابن منظور الأنصاري الرويفعى الإفريقى

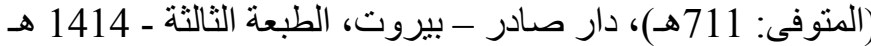

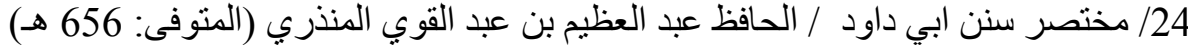

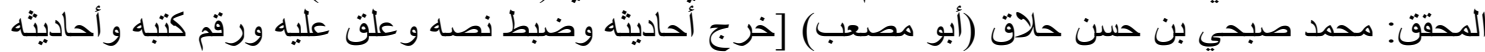




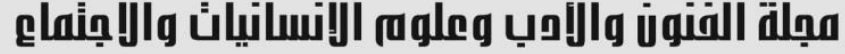

Journal of Arts, Literature, Humanities and Social Sciences www.jalhss.com

\section{Volume (63) January 2021}

يناير 2021

(63) (لعد) (2) (2)

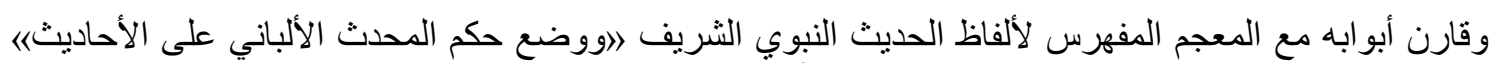

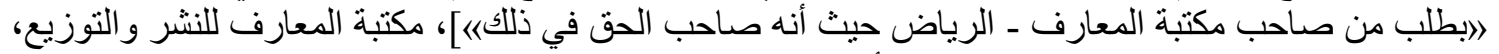

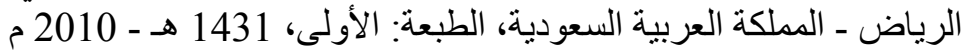

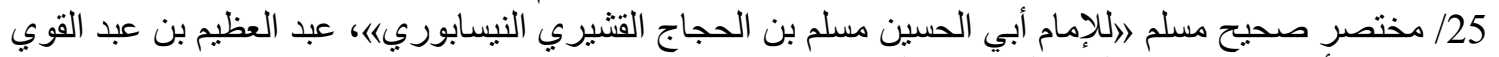

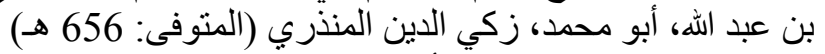

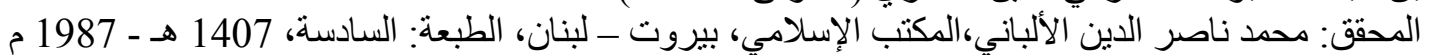

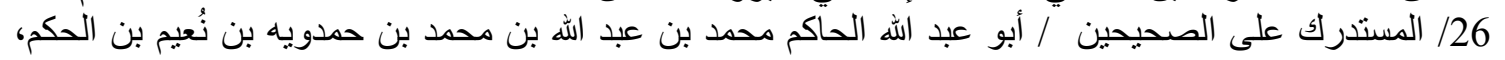

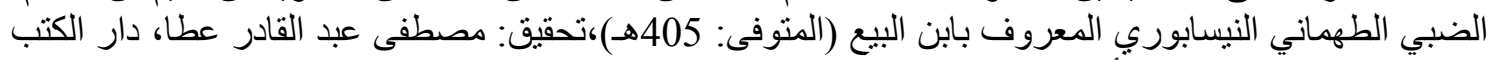

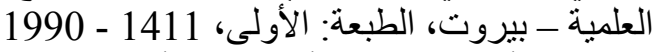

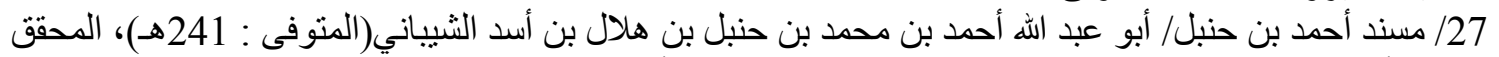

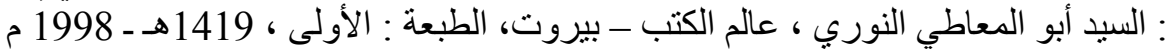

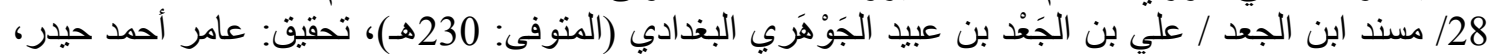

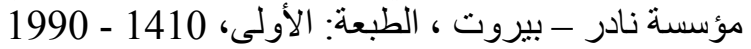

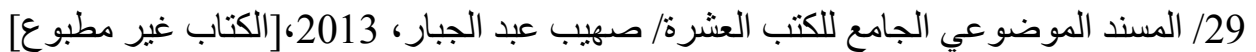

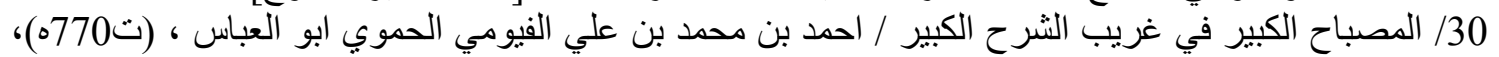

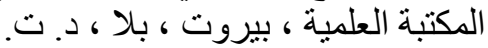

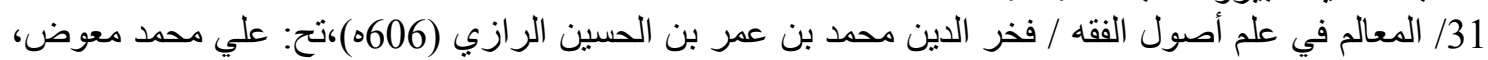

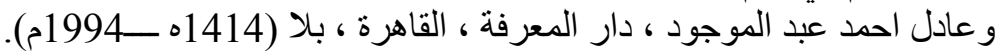

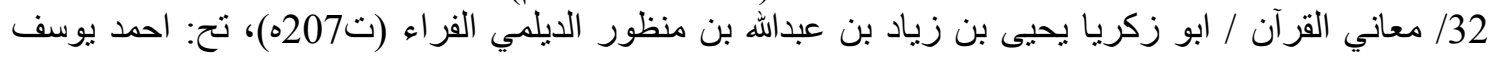

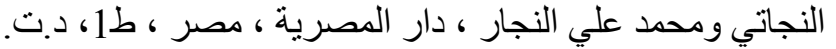

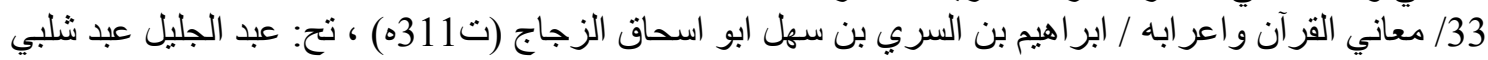

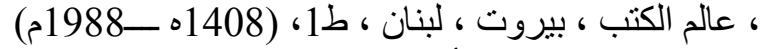

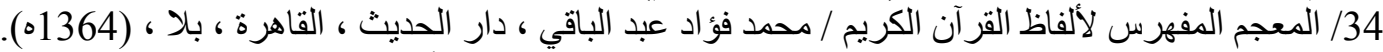

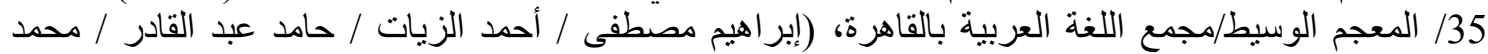

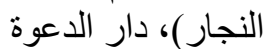

36/ المغني في فقه الإمام أحمد بن حنبل الثيبياني/عبد الله بن أحمد بن قدامة المقدسي أبو محمد

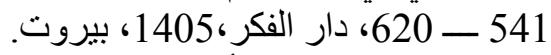

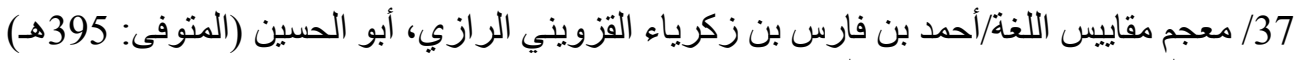

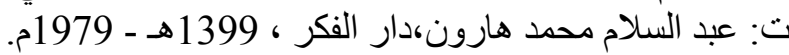

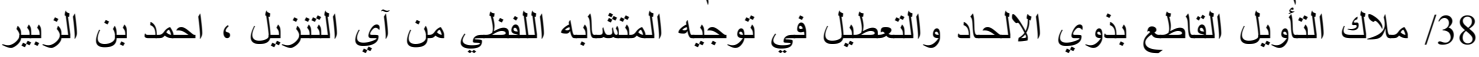

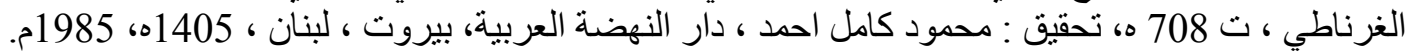
39/ مناهل العرفان في علوم القرآن / لهحمد بن عبد العظيم الزرقاني ، دار احياء التراث العربي ، دان ، بيروت ، لبنان ، 40 / الوافي بالوفيات / صلاح الدين خليل بن اييك بن عبداله الصفدي (ت764هاء)،تح: احمد الأرنؤوط ، وتركي

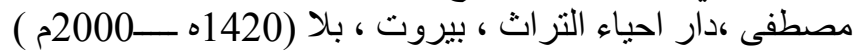

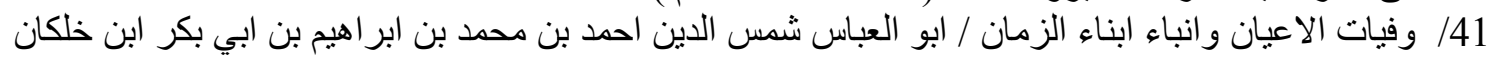

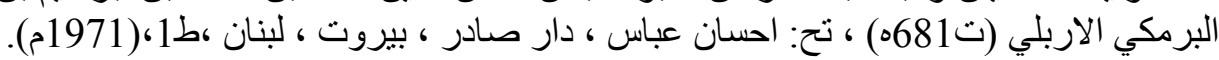

